\title{
Neurotrophin-3 Induces Neural Crest-derived Cells from Fetal Rat Gut to Develop in vitro as Neurons or Glia
}

\author{
Alcmène Chalazonitis,' Taube P. Rothman, ${ }^{1}$ JingXian Chen, ${ }^{1}$ Fabienne Lamballe, ${ }^{2}$ Mariano Barbacid, ${ }^{2}$ and \\ Michael D. Gershon' \\ 'Department of Anatomy and Cell Biology, Columbia University, College of Physicians and Surgeons, New York, New \\ York 10032 and ${ }^{2}$ Department of Molecular Biology, Bristol-Myers Squibb Pharmaceutical Research Institute, Princeton, \\ New Jersey 08543
}

The precursor cells that form the enteric nervous system (ENS) are multipotent when they arrive in the gut from the neural crest. Their differentiation thus depends on signals from the enteric microenvironment. Crest-derived cells were isolated from the fetal rat bowel by immunoselection at E14 with NC-1/HNK-1 antibodies and secondary antibodies coupled to magnetic beads. NC-1/HNK-1-immunoreactive cells were enriched $\sim 36$-fold. The NC-1/HNK-1-selected population and the residual population were plated at equal cell density and maintained in a defined medium for 6-7 d. The total number of cells found in the cultures of the residual cells was three- to fourfold that in cultures of immunoselected cells. Neurotrophin-3 (NT-3), but not nerve growth factor (NGF), brain-derived neurotrophic factor (BDNF), or neurotrophin-4/5 (NT-4/5), was found to increase the proportion of neurons (neurofilament-immunoreactive or neuron-specific enolase-immunoreactive) or glia (S-100-immunoreactive) (from $6.6 \pm 0.9 \%$ to $15.2 \pm 1.4 \% ; p<0.001$ ) This effect was concentration dependent (from 1 to $40 \mathrm{ng}$ / $\mathrm{ml}$ ) and observed only in the cultures of immunoselected cells. NT-3 also enhanced neurite outgrowth. NT-3 increased neither cell number nor bromodeoxyuridine incorporation and thus was not mitogenic. Exposure of immunoselected cells to NT-3 rapidly and transiently induced the appearance of nuclear Fos immunoreactivity. Transcripts coding for TrkC, the transducing receptor for NT-3, were identified in the fetal rat gut (E14-E 16) and in the immunoselected population of cells using reverse transcriptase and the polymerase chain reaction. It is concluded that NT-3 specifically promotes the differentiation of enteric crest-derived cells as neurons or

\footnotetext{
Received Dec. 27, 1993; revised Apr. 20, 1994; accepted Apr. 27, 1994.

We thank Ms. Edith Abreu for excellent technical assistance, particularly in the use of tissue culture, and Ms. Mary Schoenebeck for her assistance with photography. We thank Regeneron Pharmaceuticals for supplying us with all of the neurotrophins. We also thank Dr. Eran Blaugrund for preparing and purifying the HNK-1 antibody, Dr. J. P. Thiery for supplying the NC- 1 antibodies, Dr. Thomas Curran (Roche Institute of Molecular Biology, NJ) for providing an antibody to Fos protein, Dr. James Goldman (Columbia University) for providing the O4 antibody, and Dr. Richard Morrison (M. D. Anderson Cancer Center) for supplying recombinant human bFGF. This work was supported by Grants NS 15547 and HD20470 from the National Institutes of Health.

Correspondence should be addressed to Alcmène Chalazonitis, Department of Anatomy and Cell Biology, Columbia University, College of Physicians and Surgcons, 630 West 168 th Strcet, New York, NY 10032.

Copyright (C) 1994 Society for Neuroscience $0270-6474 / 94 / 146571-14 \$ 05.00 / 0$
}

glia and may thus play a role in the development and/or maintenance of the ENS.

IKey words: neurotrophins, neurotrophin-3, enteric nervous system, neural crest, gut, TrkCl

The fetal bowel is colonized by cells derived from the vagal and sacral regions of the neural crest (Le Douarin, 1982). Within the wall of the gut these cells give rise to the enteric nervous system (ENS). Vagal crest-derived cells colonize the entire bow$\mathrm{el}$, but those from the sacral crest invade only the postumbilical gut (Le Douarin and Teillet, 1973, 1974; Pomeranz et al., 1991a; Serbedzija et al., 1991). Crest-derived cells have been demonstrated to be pluripotent at the time they enter the bowel (Rothman et al., 1990, 1993); thus, the microenvironment of the gut must provide signals that are critical for the development of the ENS. Molecules in the bowel that affect the development of crest-derived cells could be diffusible factors, extracellular matrix proteins, or both.

In order to analyze the components of the enteric microenvironment that influence the development of crest-derived cells in the gut, it is advantageous to be able to study the development of enteric neurons and glia in vitro. Migrating crest-derived cells are subject to the influence of signals they encounter along their route. One property has been identified that distinguishes crestderived cells within the bowel from their pre-enteric precursors (Pomeranz et al., 1991b). This marker is a $110 \mathrm{kDa}$ cell surface laminin-binding protein (LBP110) (Smalheiser and Schwartz, 1987; Kleinman et al., 1991), which has recently been found to be a member of the $\beta$-amyloid precursor protein family (Kibbey et al., 1993). Since crest-derived cells that have completed their migration to the bowel therefore are not identical to their progenitors in the premigratory neural crest, the in vitro study of enteric neural or glial development requires that crest-derived cells be obtained from within the gut itself. Crest-derived cells have been isolated from the bowel by immunoselection (Pomeranz et al., 1993). This technique utilizes a primary antibody, such as $\mathrm{NC}-1 / \mathrm{HNK}-1$, that reacts with migrating crest-derived cells and with those differentiating as neurons or glia (Vincent et al., 1983; Vincent and Thiery, 1984; Maxwell et al., 1988; Tucker et al., 1988; Maxwell and Forbes, 1991). The antibodytreated cells are subsequently exposed to magnetic beads coated with appropriate secondary antibodies and selected with a magnet.

Neither the identity of diffusible growth factors that affect the differentiation of enteric neurons and glia nor the role such 
factors play in their development is presently known. The present study was undertaken to test the hypothesis that crest-derived cells from the bowel respond to one or more neurotrophins. There is reason to believe that such factors may be important in the development of the ENS. A previous investigation, utilizing a monoclonal antibody, IgG 192 (Chandler et al., 1984), has demonstrated that crest-derived cells express the immunoreactivity of the low-affinity nerve growth factor receptor (gp $75^{\text {LNGFR }}$ ) when they colonize the bowel (Baetge et al., 1990a). The expression of $g p 75^{\text {LNGFR }}$ thus appears in the developing rat gut as early as day E1 1 and persists into adult life. Although gp $75^{\text {LNGFR }}$ does not by itself transduce actions of the neurotrophins (I oeb et al., 1991), all of the neurotrophins bind to gp $75^{\text {LNGFR }}$ (Rodriguez-Tébar et al., 1992), and there is often coincident expression of gp $75^{\text {LNGFR }}$ with one of the high-affinity receptors (gpl40 ${ }^{r k \mathrm{~A}}, \mathrm{gpl} 45^{r k \mathrm{~B}}, \mathrm{gpl} 45^{r k \mathrm{C}}$ ) that do mediate the effects of the neurotrophins (Hempstead et al., 1991; Klein et al., 1991 a,b; Lamballe et al., 1991; Soppet et al., 1991; Squinto et al., 1991). In addition, there is evidence that enteric and sympathetic neurons develop from a common progenitor cell (Carnahan et al., 1991); the development of sympathetic neurons from this common progenitor may be influenced by its sequential exposure to combinations of growth factors that include a neurotrophin [nerve growth factor (NGF) following exposure to basic fibroblast growth factor (bFGF)]) (Birren and Anderson, 1990). Conceivably, the sequential exposure of the putative common sympathetic/enteric progenitor to a different series of growth factors and/or another neurotrophin may promote development along an enteric lineage. In a analogous fashion, a neurotrophin, brain-derived neurotrophic factor (BDNF), has been shown to promote the development of sensory neurons from crest-derived precursor cells (Sieber-Blum, 1991).

Previous studies of enteric neuronal development in vitro, which have utilized either explants or dissociated bowel, have always employed a rich growth medium supplemented with a high concentration of serum and chick embryo extract (CEE) (Dreyfus et al., 1977; Rothman and Gershon, 1982; Coulter et al., 1988; Baetge et al., 1990b; Pomeranz et al., 1993). These experiments have thus exposed the developing ENS to undefined combinations of growth factors. In the present study, therefore, a defined medium was employed for the investigation of the effects of specific neurotrophins on the development of neurons and glia from enteric crest-derived cells. Neurotrophins that were investigated included NGF (Levi-Montalcini, 1987), BDNF (Leibrock et al., 1989), neurotrophin-3 (NT-3) (Maisonpierre et al., 1990), and neurotrophin-4/5 (NT-4/5) (Berkemeier et al., 1991; Hallböök et al., 1991). Crest-derived cells were obtained by immunoselection with $\mathrm{NC}-1$ from the fetal rat gut dissociated at day E14. The antigen recognized by $\mathrm{NC}-1$ is expressed by crest-derived cells of the rat (Erickson et al., 1989) and has been found to be present on all of the cells in the E14 rat gut that are developing along a neuronal lineage (Baetge et al., 1990a). The experiments suggest that NT-3 is not a mitogen, but specifically promotes the development (and/or survival) of neurons and glia from enteric crest-derived precursor cells.

Preliminary data have been presented at the annual meeting of the Society for Neuroscience (Chalazonitis et al., 1993).

\section{Materials and Methods}

Animals. Pregnant female rats (Sprague-Dawley, Charles River, Waltham, MA) were killed by exposure to $\mathrm{CO}_{2}$ followed by thoracotomy. This procedure has been approved by the Animal Care and Use Com- mittee of Columbia University. Pregnancy was timed from the day of breeding, which was designated as day 0 . The fetal bowel was dissected aseptically from 20-22 fetuses/experiment at $14 \mathrm{~d}$ of gestation (E14).

Cell dissociation and immunoselection. The method previously employed by Pomeranz et al. (1993) to immunoselect crest-derived cells from the developing avian and murine bowel was adapted for use in the fetal rat. Essentially, the bowel from each fetus was collected and stored in iced Hank's solution (pH 6.9). The preparations were then rinsed and later minced in $\mathrm{Ca}^{2+} / \mathrm{Mg}^{2+}$-free saline (CMFS) supplemented with glucose. The minced gut was incubated with $0.5 \%$ collagenase (type A, Boehringer Mannheim) at $37^{\circ} \mathrm{C}$ for $25-30 \mathrm{~min}$, and rinsed twice with $\alpha$-minimal essential medium ( $\alpha$-MEM; GIBCO) supplemented with $20 \%$ horse senum (HS; JRH Biosciences, Lenexa, KS) and 10\% CFF (made from E11 embryos). The collagenase-treated tissue was dissociated by trituration. The resulting cell suspension was filtered through a $53 \mu \mathrm{m}$ nylon mesh (Small Parts Inc., Miami, FL) to remove undissociated cells. The yield, calculated in 12 experiments, averaged $22.2 \pm 1.9 \times 10^{6}$ cells. The dissociated cell suspension was incubated for $1 \mathrm{hr}$ at $4^{\circ} \mathrm{C}$ with the NC-1 monoclonal antibody (from Dr. J. P. Thiery, Ecole Normale Supérieure, Paris; diluted 1:2) or HNK-1 prepared from hybridoma TIB 200 cells (obtained from the American Type Culture Collection, Rockville, MD; diluted 1:100). Following incubation, the cells were collected by centrifugation $(100 \times g, 5 \mathrm{~min})$, washed with $\alpha$-MEM, and resuspended in $\alpha$-MEM containing magnetic beads coated with a goat antibody to mouse IgM (Advanced Magnetics, Cambridge, MA; $9 \mu \mathrm{g} / \mathrm{ml}$ ). The concentration of IgM-coated magnetic beads was chosen to provide $\sim 10$ coated beads (manufacturer's recommendation) for each NC-1labeled cell. This calculation assumed that such cells constituted $\sim 10 \%$ of the original cell suspension. A 10 -fold lower concentration of beads failed to immunoselect cells, a 10-fold higher concentration did not select a greater number of cells, and a 100 -fold higher concentration was toxic. A magnetic separator (BioMag Separator, Collaborative Research) was then used to separate the antibody-labeled cells from the remaining cells of the suspension. Both the NC-1-immunoselected and the residual cells were resuspended in Basic Brazeau Medium (BBM) (Brazeau et al., 1981; Ziller et al., 1983), supplemented with $20 \%$ HS. In order to optimize the yield, the residual cells were subjected to a second round of immunoselection carried out as above. The cells selected by this additional procedure were added to the first. In 12 experiments, the average final yield of immunoselected cells was $3.0 \pm$ $0.4 \times 10^{6}$ cells. If the primary antibody was omitted, about $25 \%$ of this number of cells was carried nonspecifically by the beads. The yield of immunoselected crest-derived cells was thus about $10 \%$ after correction for nonspccific binding.

Cell cultures and maintenance. Cultures were grown in BBM. This medium is supplemented with cortisol $(100 \mathrm{ng} / \mathrm{ml})$, insulin $(1 \mathrm{ng} / \mathrm{ml})$, triiodothyronine $(400 \mathrm{pg} / \mathrm{ml})$, parathyroid hormone $(200 \mathrm{pg} / \mathrm{ml})$, glucagon $(10 \mathrm{pg} / \mathrm{ml})$, epidermal growth factor (EGF; $1 \mathrm{ng} / \mathrm{ml}$ ), bFGF [10 $\mathrm{ng} / \mathrm{ml}$; human recombinant (UBI, Lake Placid, NY, or donated by Dr. R. Morrison, M. D. Anderson Cancer Center, Houston, TX) diluted in $0.02 \%$ CHAPS], and transferrin $(10 \mu \mathrm{g} / \mathrm{ml})$. Culture dishes (Falcon 3001$)$ were coated with rat tail collagen $(430 \mu \mathrm{g}$ of protein $/ \mathrm{ml})$ and laminin $(10 \mu \mathrm{g} / \mathrm{ml}$; Collaborative Research). Suspensions of immunoselected as well as unselected cells were diluted with BBM containing $20 \% \mathrm{HS}$ and plated at a density of $2.75 \times 10^{5}$ cells/dish. In order to facilitate attachment, cells were allowed to settle for 16-18 hr in HS-containing BBM. This medium was then replaced with serum-free BBM for the remainder of the experiment. The effects of several neurotrophins (NGF, BDNF, NT-3, NT-4/5; supplied by Regeneron Pharmaceuticals, Tarrytown, NY) were analyzed. NGF was purified from male mouse submaxillary glands, while the other neurotrophins were recombinant human products purified from the conditioned media of Chinese hamster ovary (CHO) cells expressing the individual proteins (DiStefano et al., 1992). Each type of neurotrophin-treated culture was maintained in triplicate and all experiments included controls in which neurotrophins were omitted. Neurotrophins to be tested were added at the time of plating and were maintained at a constant concentration for the duration of the culture period (see Results). Equal volumes of vehicle into which the neurotrophins were dissolved (containing $1 \% \mathrm{HS}$ or $1 \% \mathrm{BSA}$ ) were added to control cultures. Cultures were fed by replacing half of the volume of medium after $4 \mathrm{~d}$. Cultures were fixed after $7 \mathrm{~d}$. In addition to the studies carried out with cells grown in BBM, the effect of NT-3 was also investigated in cells that were grown in $\alpha$-MEM containing $10 \% \mathrm{HS}$.

Immunocytochemistry. Neurons were identified either with polyclonal antibodies to neuron-specific enolase (NSE; diluted 1:1000; Polysci- 
ences, Warrington, PA) or with a cocktail of monoclonal antibodies to the 68,160 , and $200 \mathrm{kDa}$ components of the neurofilament triplet (each diluted 1:100; Sigma Chemical Co.). Glia were identified with polyclonal antibodies to the bovine $\mathrm{S}-100$ protein (diluted 1:400; DAKO A/S, Denmark) or with a monoclonal antibody, $\mathrm{O} 4$, which is known to react with an epitope found on oligodendroglia and Schwann cells (diluted 1:5; gift of Dr. James Goldman, Columbia University). The monoclonal antibody HNK-1 (diluted 1:200) was used to follow the retention of the epitope used in immunoselection and to evaluate the efficiency of the immunoselection procedure. The epitope recognized by HNK- 1 is identical to that recognized by NC-1 (Tucker et al., 1984). Expression of the c-fos proto-oncogene was evaluated immunocytochemically by using two different polyclonal antibodies to Fos. Ab-2 (diluted 1:2000; Oncogene Science Inc., NY) is an affinity-purified antibody that is directed against amino acid residues 4-17 of the human Fos protein. The second anti-Fos reagent was an antibody that recognizes the $\mathrm{N}$-terminal segment of the recombinant Fos protein (diluted 1:2000; gift of Dr. Thomas Curran, Roche Institute of Molecular Biology).

For detection of intracellular antigens, the cultures were rinsed in Tris-buffered saline (TBS) containing $0.1 \%$ Triton X-100 (Sigma) to permeabilize cells. The preparations were then incubated for $1 \mathrm{hr}$ in TBS containing Triton X-100 (0.1\%) and $10 \%$ HS to reduce background staining. For detection of membrane antigens, the cultures were treated as above, but Triton X-100 was omitted. With the exception of antibodies to Fos, cultures were exposed overnight at room temperature to primary antibodies dissolved in TBS containing 4\% HS. Primary antibodies against Fos were applied for $\sim 80 \mathrm{hr}$ at $4^{\circ} \mathrm{C}$. The antibodytreated cultures were rinsed and exposed for $3 \mathrm{hr}$ at room temperature to an appropriate affinity-purified species-specific secondary antibody. Secondary antibodies included goat anti-rabbit IgG labcled with alkalinc phosphatase, diluted 1:50; goat anti-mouse IgG labeled with horseradish peroxidase (HRP), diluted 1:100; goat anti-mouse IgM labeled with HRP, diluted 1:50 (all from Kirkegaard and Perry Labs, Gaithersburg, $\mathrm{MD}$ ); and biotinylated goat anti-rabbit IgG in conjunction with avidinHRP (ABC kit, Vector Laboratories, Burlingame, CA). Following exposure to secondary antibodies, the cultures were rinsed with TBS. Commercial kits from Vector Laboratories (alkaline phosphatase) and Kirkegaard and Perry (HRP) were utilized to visualize sites of immunoreactivity as described previously (Pomeranz et al., 1993). Controls, in which the primary antibody was omitted, were always included with the experimental preparations.

Proliferation of neural and glial precursors. The proliferation of cells was assessed by studying the incorporation of bromodeoxyuridine (BrdU) into DNA. Briefly, cultures were exposed to $\operatorname{BrdU}(10 \mu \mathrm{M})$ for $24 \mathrm{hr}$ in the absence or presence of NT-3 $(10 \mathrm{ng} / \mathrm{ml})$. The medium was then replaced and incubation was continued for 1 week. Cultures were then fixed with absolute methanol for $10 \mathrm{~min}$ at $-20^{\circ} \mathrm{C}$. Secondary antibodies labeled with alkaline phosphatase were used to demonstrate NSE or S-100 immunoreactivity. DNA in the cells was then denatured by incubating the preparations with $4 \mathrm{~N} \mathrm{HCl}$ for $10 \mathrm{~min}$ at room temperature. After rinsing several times in cold borate buffer $(\mathrm{pH} 8.5)$, followed by a rinse in TBS, the cultures were exposed overnight to monoclonal antibodies to BrdU (diluted 1:20; Becton-Dickinson, Mouton View, $\mathrm{CA}$ ). BrdU immunoreactivity was visualized with secondary antibodies labeled with HRP. Doubly labeled cells, indicative of neurons or glia that had completed their terminal mitosis during the $24 \mathrm{hr}$ period of exposure to BrdU, could be recognized as cells in which the cytoplasm contained the blue alkaline phosphatase reaction product, and the nuclei contained the black HRP reaction product.

Cell counts. At various times after plating, cultures were rinsed with cold Hank's solution, fixed for $1 \mathrm{hr}$ with $4 \%$ formaldehyde (freshly prepared from paraformaldehyde) in $0.1 \mathrm{M}$ sodium phosphate buffer at pH 7.4, and rinsed with $0.1 \mathrm{M}$ PBS. Counts of non-neuronal and processbearing cells (which include both neurons and glia) in each dish were carried out using phase-contrast optics and a protocol that has been described previously (Chalazonitis et al., 1992). Essentially, cells were counted at a magnification of $200-300 \times$ through a $1 \mathrm{~cm}$ strip in $\mathrm{x}$ - and $y$-axes of the dish. In other experiments, immunostained cells were counted by means of an identical protocol. Student's $t$ test was used to compare means, and multiple factors were compared to one another by ANOVA (STATVIEW 4.0 program for the Macintosh computer).

Measurement of neuritic process length. The length of neurites was quantified using a computerized imaging system (MCID 4.2, Imaging Research Inc., Ontario, Canada). Neurons were identified with phasecontrast optics in triplicate cultures of immunoselected cells that had been maintained for 1 week in BBM either with NT-3 $(40 \mathrm{ng} / \mathrm{ml})$ or without (control). The $\mathrm{x}$-axis of each dish was scanned at a magnification of $250 \times$. A total sample of $\sim 100$ neurons, derived from 33-34 cells/ dish, was obtained. Only cells bearing neurites of measurable length were analyzed. If a cell exhibited more than one neurite, only the longest was measured.

Detection of $m R N A$ encoding trk $C$. The presence of mRNA encoding trkC was assayed by utilizing reverse transcriptase and the polymerase chain reaction (RT-PCK). RNA was extracted from E14 and E16 rat gut with $6 \mathrm{M}$ guanidinium thiocyanate (Chomczynski and Sacchi, 1987). In most experiments, polyA + RNA was prepared from total RNA on oligo(dT)-cellulose (QuickPrep kit, Pharmacia Biotech, Piscataway, NJ, using the protocol suggested by the manufacturer) prior to RT-PCR. Either total RNA or polyA + RNA was incubated with Moloney Murine Leukemia Virus reverse transcriptase (GIBCO-Bethesda Research Labs, Bethesda, MD) in the presence of oligo(dT) using the protocol provided by the supplier. The resulting cDNA was amplified by means of the polymerase chain reaction (PCR) using the following pairs of amplimers: FL52-1 (5'-CACGAGGAATTCCCTGGTTGGAGCCAATCTACT AGTG-3') and FL53-1 (5'-CGAAGCTCTAGACATCACTCTCTGTGGTGAACTTCCGGTAC-3'). These amplimers correspond, respectively, to nucleotides 2074-2110 and 2218-2258 of pFL19, a cDNA clone encompassing the entire coding sequences of the TrkC $\mathrm{K} 1$ receptor (Lamballe et al., 1991), except for the nucleotides 2083, 2085, 2248, and 2250 , which were changed to create EcoRI and XbaI sites as described earlier (Lamballe et al., 1993). These amplimers correspond to sequences encoding part of the catalytic tyrosine kinase domain of TrkC (T amballe et al., 1991); therefore, they should not amplify sequences coding for noncatalytic isoforms of the TrkC receptor. PCRs were performed at an annealing temperature of $56^{\circ} \mathrm{C}$ for 35 cycles. The primers were used at a concentration of $0.2 \mu \mathrm{M}$. The PCR products were separated by electrophoresis through a $2 \%$ agarose gel and transferred onto Duralon-UV membranes (Stratagene) for Southern blot analysis. Positive controls were run in parallel and were utilized to identify the PCR products corresponding to $t r k C$ sequences. Parallel PCR amplifications were performed on a cDNA clone encoding the tyrosine kinase catalytic domain of mouse TrkC ( $\mathrm{pFL} 35$ ), and on adult rat brain, which was processed in the same way as the tissue from the fetal bowel. cDNA encoding $\beta$-actin was amplified in parallel in each experiment. In order to determine whether samples were contaminated with genomic DNA, PCR was carried out with material that was not exposed to RT. No contaminating genomic DNA was encountered. A second series of amplimers, based on the sequence of rat trkC (Valenzuela et al., 1993), was synthesized and used to generate a probe corresponding to sequences internal to those described above. This probe was used to confirm the identity of the PCR products by Southern blotting. These amplimers had the following sequences: 5'-CATGTCCAGGGACGTCTACA-3' and 5'-GA TGCTTTCAGGTGGCATCC-3', which correspond respectively to nucleotides 2097-2116 and 2301-2281 of the rat $t r k C$ sequence. RTPCR was repeated using this second set of amplimers on pFL35 as a template. The PCR product was purified, radiolabeled with $\alpha{ }^{32} \mathrm{P}-\mathrm{dCTP}$ $(800 \mathrm{Ci} / \mathrm{mmol}$; Amersham) by random priming, and used as a probe for Southern blot analysis.

\section{Results}

Crest-derived cells can be immunoselected efficiently from the fetal rat gut with $N C-1 / H N K-1$ antibodies

The NC-1 monoclonal antibody has previously been used to immunoselect crest-derived cells from the developing avian bowel and from the fetal rat gut at El 1 (Pomeranz et al., 1993). Initial experiments were therefore carried out to evaluate the efficacy of NC-1 for the immunoselection of crest-derived cells from the fetal rat bowel at day E14, the age selected for the present study. After $14 \mathrm{hr}$ in BBM $20 \% \mathrm{HS}$, to permit attachment, cells were fixed and processed for the visualization of $\mathrm{NC}$ $1 / \mathrm{HNK}-1$. A large percentage of immunoselected cells died during the first $14 \mathrm{hr}$ after plating (Fig. $1 \mathrm{~A}$ ), and thus the total number of unselected cells at this time was significantly greater than that of immunoselected cells (Fig. $1 A$ ); however, signifcantly more NC-1/HNK-1-immunoreactive cells were present in the immunoselected than in the unselected cultures (Fig. $1 B$ ). As a result, the proportion of $\mathrm{NC}-1 / \mathrm{HNK}-1-\mathrm{imm}$ unoreactive 

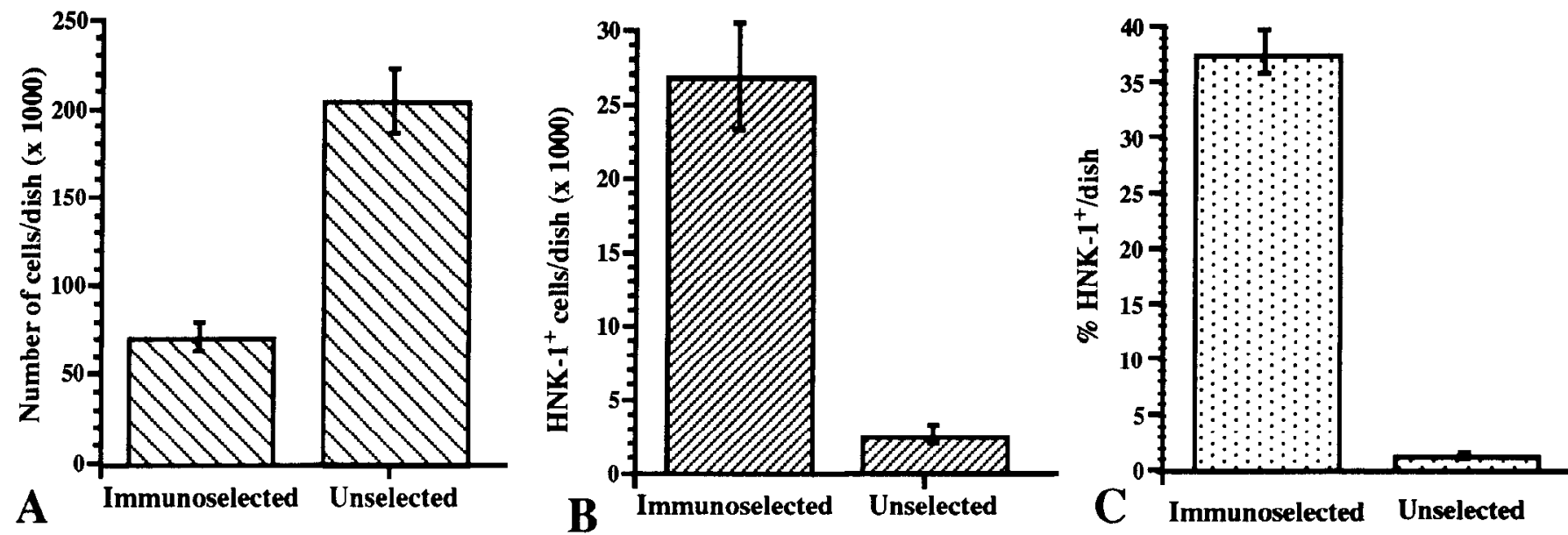

Figure 1. Efficacy of NC-1 immunoselection in the fetal rat gut. Four cultures of NC-1 immunoselected and five cultures of unselected cells were maintained for $14 \mathrm{hr}$ in BBM with $20 \% \mathrm{HS}$. The number of cells in each dish was determined and HNK-1 immunoreactivity was then demonstrated. Values shown represent means \pm SE. $A$, Total cell numbers $(p<0.001)$. $B$, HNK-1-immunoreactive cell numbers $(p<0.001)$. $C$, Percentage of cells that were HNK-1 immunoreactive $(p<0.0001)$.

cells was substantially greater ( 36 -fold; $p<0.0001$ ) in the cultures of immunoselected cells (Fig. 1C). The number of HNK1-immunoreactive cells in the cultures of immunoselected cells was probably underestimated, because some of the immunostained cells were masked by overlying magnetic beads, which were themselves immunoreactive. These data indicate that immunoselection with $\mathrm{NC}-1$ is effective for obtaining populations enriched in crest-derived cells from the E14 fetal rat gut.

\section{$N T-3$ increases the proportions of neurons and glia in cultures of immunoselected cells}

In four separate experiments, immunoselected and unselected cells were grown for 5-7 d in BBM in the presence or absence of NT-3 $(40 \mathrm{ng} / \mathrm{ml})$. This concentration of NT-3 was chosen because it has been demonstrated to be greater than the concentration at which NT-3 was found to exert a maximal effect on neurite outgrowth in a mutant neuronal cell line (PC12nnr5/ trkC) that expresses only TrkC (Ip et al., 1993b). After 5-7 d in vitro, the total number of cells as well as the numbers of neurons (neurofilament- or NSE-immunoreactive) and glia (S100-immunoreactive) in each culture dish were determined. In order to normalize the data between experiments, the quantity of neurons or glia was expressed as a percentage of the total number of cells in each dish (Fig. $2 A$ ).

In the cultures of immunoselected cells, exposure to NT-3 induced a greater than twofold increase $(p<0.01)$ in the percent of neurons (Fig. $2 A$ ). Similarly, the proportion of glia also more than doubled $(p<0.005)$ in cultures treated with NT-3 (Fig. $2 A)$. Since both neurons and glia arise from crest-derived cells, the effect of NT-3 on the summed proportions of these cells as well as its action on each alone were also determined. As with the individual cell types, NT-3 evoked a significant increase ( $p$ $<0.001)$ in the combined proportion of neurons plus glia $(15.2$ $\pm 1.4 \% ; n=7)$ compared to untreated cultures $(6.6 \pm 0.9 \% ; n$ $=6$ ) (Fig. $2 A$ ). Interestingly, counts made with phase-contrast optics, in which neurons and glia were identified together as process-bearing cells, yielded similarly higher percentages in the NT-3-treated cultures: $12.3 \perp 2.7 \%(n=8)$ than in control cultures: $3.9 \pm 0.77 \%(n=8)$; this observation suggests that phase-contrast counts of process-bearing cells can be used to quantify the aggregate numbers of neurons and glial cells de- veloping in cultures. The monoclonal antibody, $\mathrm{O} 4$, which recognizes a sulfatide in lipid extracts of Schwann cells and is a marker that appears in developing Schwann cells prior to galactocerebroside (Mirsky et al., 1990; Jessen and Mirsky, 1992), was also examined in five cultures (two NT-3-treated and three controls). About $8 \%$ of cells were immunostained by the $\mathrm{O} 4$ antibody in control cultures and $\sim 11 \%$ of cells were immunostained in the cultures exposed to NT-3.

The time dependence of the promotion by NT-3 of the differentiation of neurons and glia was investigated in an additional experiment. The number of process-bearing cells, evaluated in duplicate cultures at $1,3.5$, and $7 \mathrm{~d}$, increased progressively as a linear function of time $(r=0.9 ; p<0.02)$. The rate of increase in the presence of NT-3 was about 2.5 -fold that in control cultures.

In order to determine whether the action of NT-3 is affected by serum, immunoselected cells were plated in the presence of $10 \% \mathrm{HS}$ and maintained for 1 week in the presence of $5 \% \mathrm{HS}$. The proportion of process-bearing cells was again increased [from $2.4 \pm 0.3 \%(n=5)$ to $4.8 \pm 0.4 \%(n=6) ; p<0.001]$ by NT3 ; therefore, serum does not interfere with the ability of NT-3 to promote the development of neurons and/or glia. The proportion of neurons developing in serum-containing media was less than that found in defined media, because the number of non-neuronal cells was enhanced (approximately threefold) by serum.

\section{The ability of NT-3 to promote the development of neurons and glia is not seen in cultures of unselected (residual) cells}

Since NT-3 was found to exert a biological effect on the crestderived cells in immunoselected cultures, it was important to determine whether it would act similarly when applied to the non-crest-derived cells in unselected cultures. Data were normalized by obtaining the ratio of the proportion of neurons or glia in NT-3-treated $(40 \mathrm{ng} / \mathrm{ml})$ cultures (immunoselected or residual) to the proportions of these cells in the corresponding control cultures not exposed to NT-3 (Fig. 2B). These ratios would be expected to be 1 if NT-3 were to have no effect on neuronal or glial development, and a ratio significantly greater than 1 would indicate that NT-3 promotes the appearance of these phenotypes. As expected from the experiments described 

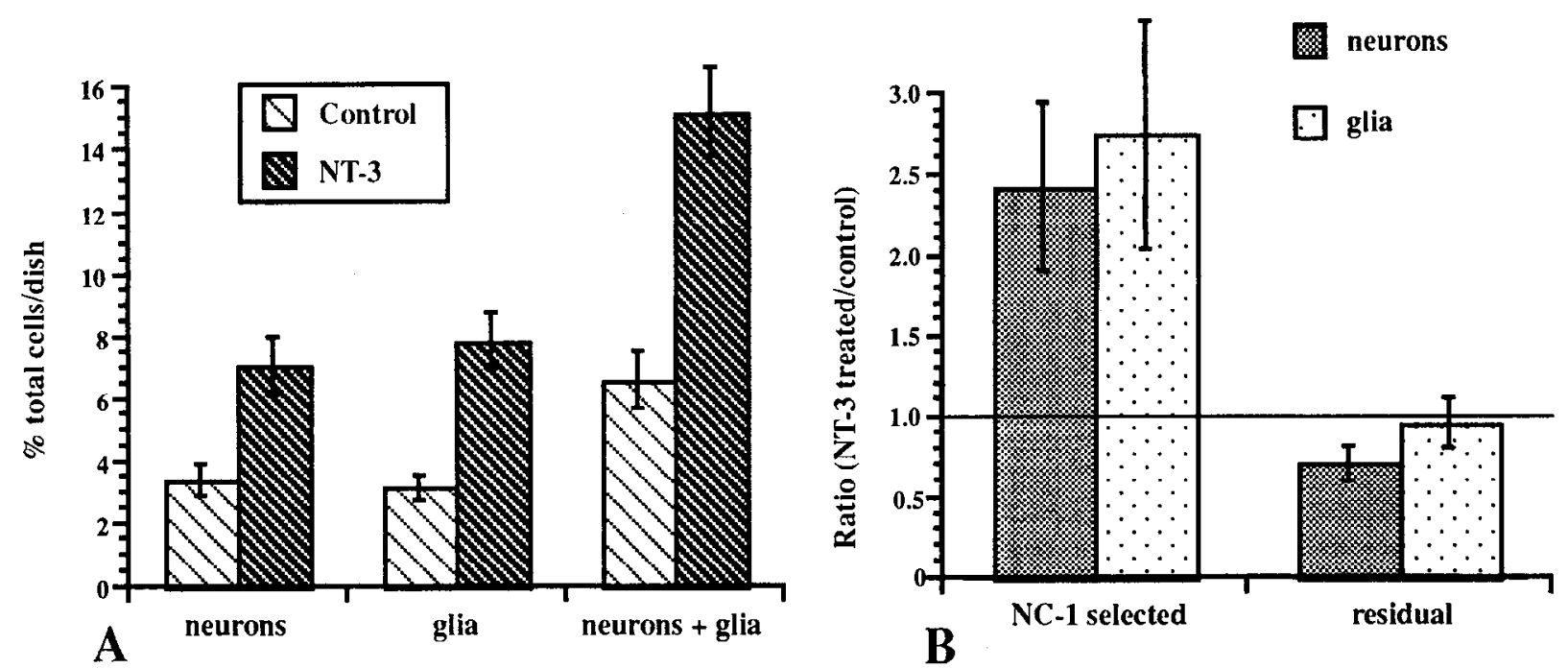

Figure 2. Promotion by NT-3 of the appearance of neurons and glia. $A$, The effect is seen in cultures of NC-1/HNK-1-immunoselected cells. Cultures were maintained for $7 \mathrm{~d}$ in the presence or absence of NT $-3(40 \mathrm{ng} / \mathrm{ml})$. Neurons were identified with antibodies to neurofilament proteins or NSE. Glia were detected with antibodies to the S-100 protein. The graph shows data pooled from four experiments $(n=6-8$ cultures grown under each set of experimental conditions). NT-3 significantly increased the proportion of neurons $(p<0.01)$, glia $(p<0.005)$, and the aggregate of neurons + glia $(p<0.001)$. B. The cffect is not detected in cultures of unselected (residual) cells. The ratios (NT-3-treated:control) of the proportions of neurons and glia developing in cultures of immunoselected and residual cells are compared. Neurons and glia were identified as described in $A$. The horizontal line shows the ratio (1) that would be expected if NT-3 had no effect. Data were obtained from four separate experiments and pooled. The graph shows the means $\pm \mathrm{SE}(n=6-8$ cultures grown under each set of experimental conditions). The actual proportion of neurons in NT-3-treated cultures of residual cells was $4.5 \pm 2.0 \%$, while that in control cultures of residual cells was $6.3 \pm 2.5 \%$. The actual proportion of glia in NT-3-treated cultures of residual cells was $5.2 \pm 1.9 \%$, while that in control cultures of residual cells was $6.6 \pm 3.0 \%$.

above, NT-3 significantly increased the ratio (NT-3-treated/ control) of neurons $(p<0.02)$ and glia $(p<0.03)$ developing in cultures of immunoselected cells ( $\sim 2.5$-fold); however, in the cultures of residual cells these ratios were not significantly higher than 1 (Fig. 2B).

\section{The effect of NT-3 on the development of neurons and glia in vitro is concentration dependent}

The concentration-effect relationship for the promotion of neuronal and glial development in cultures of immunoselected cells was ascertained. Concentrations of NT-3 from 0.1 to $100 \mathrm{ng}$ / $\mathrm{ml}$ were tested. After 6-7 d of growth in the absence (control) or in the presence of each concentration of NT-3, counts were made of total and process-bearing cells. Process-bearing cells were counted, because the number of these cells had previously been found to reflect the sum of neurons + glia in the cultures (see above). At each concentration of NT-3 the proportion of process-bearing cells was normalized to that found in untreated cultures (Fig. 3). The lowest concentration of NT-3 found to increase the proportion of process-bearing cells significantly was $1.0 \mathrm{ng} / \mathrm{ml}(p<0.05)$. The effect of NT-3 was maximal at 40 $\mathrm{ng} / \mathrm{ml}(\sim 250 \%$ of control) and declined significantly at $100 \mathrm{ng} /$ $\mathrm{ml}(p<0.02)$, although at this concentration the action of NT-3 was still significantly higher than control $(p<0.007)$.

\section{NT-3 transiently induces expression of Fos immunoreactivity}

The ability of NT-3 to induce expression of the $c$-fos protooncogene was assessed by demonstrating Fos, the protein encoded by this gene in the nuclei of immunoselected cells in vitro. The two antibodies used for this purpose (Ab-2 of Oncogene Sciences and an antibody provided by Dr. Thomas Curran) provided qualitatively similar patterns of immunostaining. Cultures of immunoselected cells were maintained for $40 \mathrm{hr}$ in BBM alone. These cultures were then divided into experimental and control groups. NT $-3(40 \mathrm{ng} / \mathrm{ml})$ was added to the experimental group of cultures, which were then maintained for a further 12 or 24 hr. Control cultures were treated identically as the experimentals, except that the controls received only the vehicle ( $1 \%$ BSA) in which NT-3 was dissolved. The number of Fosimmunoreactive cells in the cultures treated with NT-3 [9307 $\pm 1192(12.0 \pm 2.3 \%), n=9$ cultures] was almost fourfold

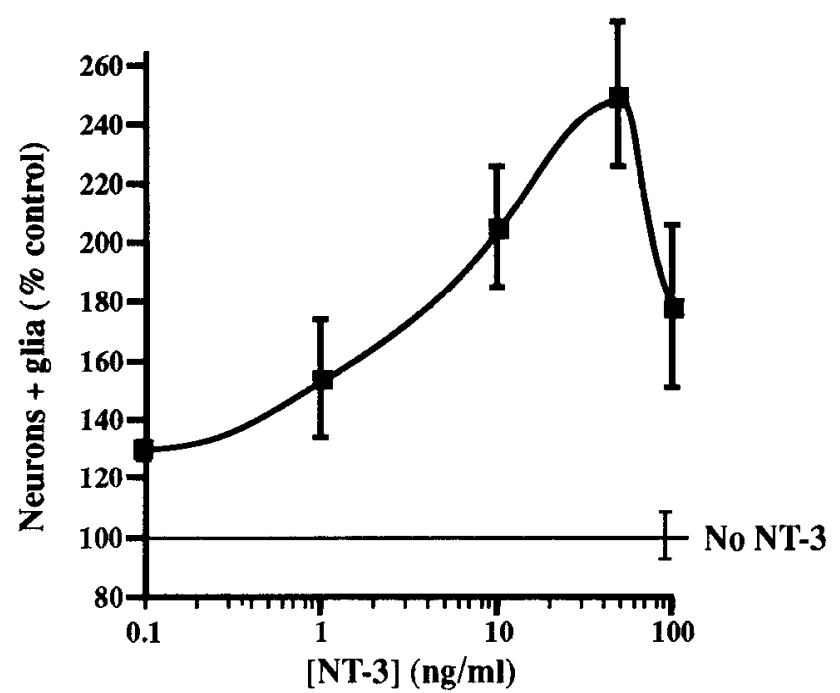

Figure 3. The concentration-effect relationship for the promotion by NT-3 of the development of neurons and glia. The ability of NT-3 to promote the appearance of process-bearing cells (neuron + glia) in vitro is plotted as a function of the concentration of NT-3. Data are expressed as percentage of control (mean $\pm \mathrm{SE}$ ). The control was taken as the proportion of process-bearing cells developing in vitro in the absence of NT-3 (horizontal line). At $0.1 \mathrm{ng} / \mathrm{ml} n=3$ cultures; at $1.0 \mathrm{ng} / \mathrm{ml} n$ $=7$ cultures; for the remaining points, $n=6$ cultures. 

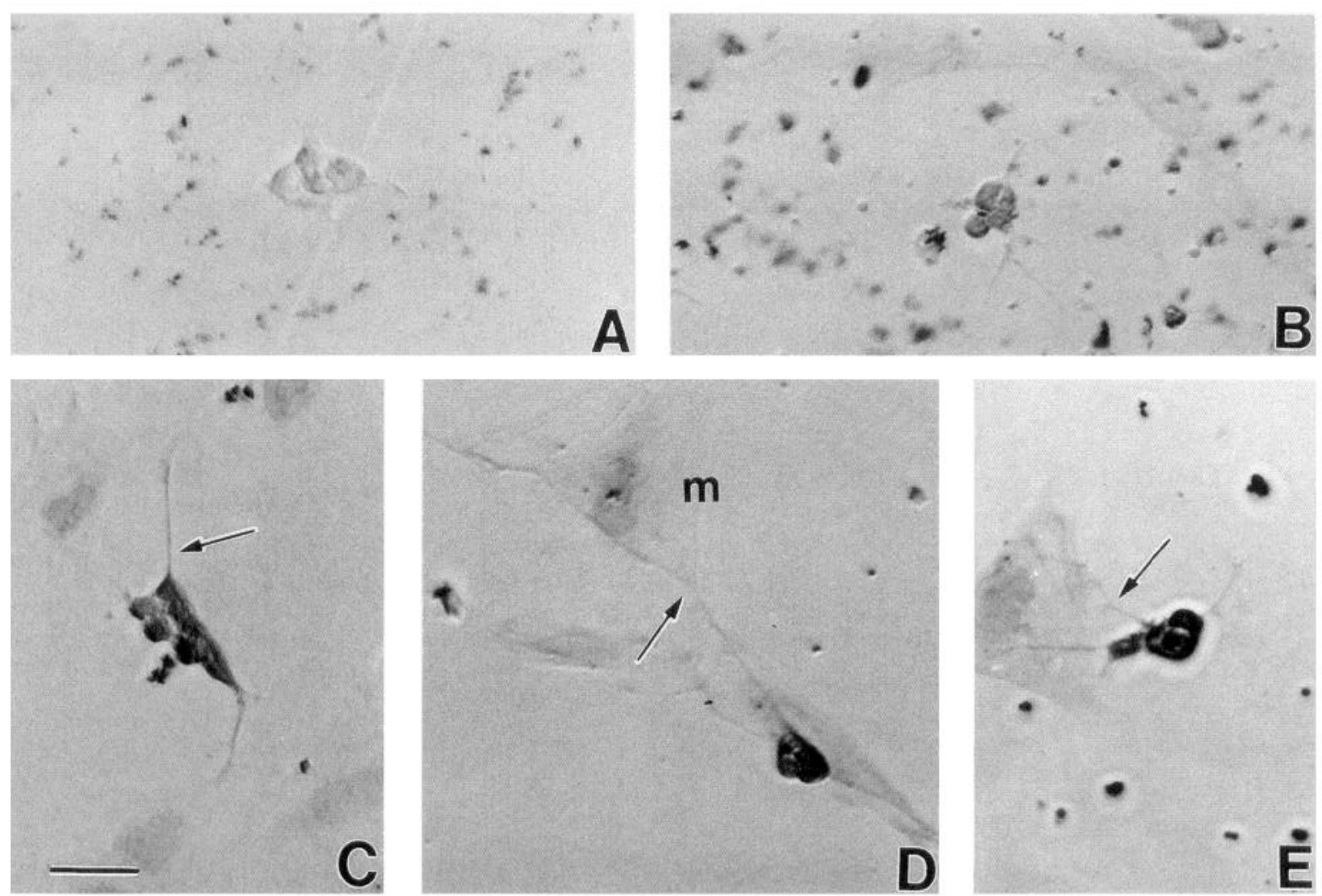

Figure 4. NT-3 induces the expression of Fos immunoreactivity in process-bearing cells. $A$, Immunocytochemical control. The culture was exposed for $2 \mathrm{hr}$ to NT-3 $(40 \mathrm{ng} / \mathrm{ml})$, but the primary antibody to Fos was omitted. B, Vehicle. The culture was exposed for $2 \mathrm{hr}$ to the vehicle in which NT-3 was dissolved. The culture was immunostained with antibodies to Fos. $C-E$, NT-3. The cultures were exposed for $1 \mathrm{hr}(C, D)$ or $2 \mathrm{hr}(E)$ to NT-3. The cultures were immunostained with antibodies to Fos. Note that the immunostained cells are process bearing (arrows). Some diffusion of reaction product occurred because of the very intense reaction product in the nuclei of immunoreactive cells. Cells with a mesenchymal appearance $(m)$ do not show Fos immunoreactivity. Scale bar, $25 \mu \mathrm{m}$.

greater than that in the cultures exposed only to the vehicle $[1861 \pm 1247(2.9 \pm 1.1 \%), n=4$ cultures $)(p<0.003)$. In contrast to the effect of NT-3 on Fos expression at 1-2 hr, the number of Fos-immunoreactive cells was not significantly different from background when cells were examined after $24 \mathrm{hr}$ of incubation in the presence of NT-3 (average $=350$ cells; $n$ $=2$ cultures). These data indicate that the induction of Fos immunoreactivity by NT-3 is transient.

Fos immunoreactivity was limited in most cells to the nucleus [compare Fig. 4, $A$ (control) to $C-E$ (NT-3-treated)]. Cells exposed to the vehicle alone generally expressed lower levels of Fos immunoreactivity than did those exposed to NT-3 (compare Fig. 4, $B$ with $C-E$ ). Fos-immunoreactive cells, in the NT-3treated cultures, were typically process bearing; cells with a mesenchymal appearance were not immunostained (Fig. 4C-E). The intensity of the Fos immunoreactivity after $2 \mathrm{hr}$ exposure to NT-3 was not distinguishably different from that at $1 \mathrm{hr}$. Although Fos immunoreactivity was mainly confined to process-bearing cells, not all of these cells were immunostained by antibodies to Fos.

\section{$N T-3$ enhances neurite outgrowth}

Although NT-3 clearly promoted the appearance of neurons in vitro, some neurons were found to develop in cultures of immunoselected cells, even in the absence of exogenous neurotrophin. Neurites, however, were much longer (Fig. 5) when neurons developed in the presence of NT-3 (mean $=107.4 \pm 6.0$ $\mu \mathrm{m} ; n=101)$ than when they developed in its absence $(71.9 \pm$ $9.6 \mu \mathrm{m} ; n=104 ; p<0.03)$. In the NT-3-treated cultures, moreover, the proportion $(\sim 80 \%)$ of the population of neurons with very long neurites $(60-180 \mu \mathrm{m})$ was much higher than that in the controls $(\sim 25 \%)$ (Fig. 6).

Promotion of neural and glial development is NT-3 specific; it is not manifested by other neurotrophins

The specificity of the response to NT-3 was studied by determining whether NGF, BDNF, or NT- $4 / 5$ affect the development of neurons and glia in cultures of immunoselected crest-derived and unselected (residual) cells. Each neurotrophin was added to the cultures at $50 \mathrm{ng} / \mathrm{ml}$ (close to that which elicits a maximal effect), which were then maintained for 6-7 d. In the cultures of immunoselected cells, no significant change in total cell numbers (control mean $=58,200 \pm 8400 ; n=8$ cultures) was induced by the addition of any neurotrophin (Fig. $7 A$ ). In contrast, the proportion of cells developing as neurons or glia was significantly increased by NT-3 [from $3.4 \pm 0.4 \%(n=8)$ in control to $8.1 \pm 0.8 \%(n=10) ; p<0.0001]$, but by no other neurotrophin (Fig. $7 B$ ). NT-3, NGF, BDNF, and NT-4/5 did not affect the proportion of cells developing as neurons and glia in the cultures of unselected (residual) cells (data not illustrated). These observations suggest that NT-3 is the only neurotrophin that affects the development of neurons and glia from crestderived cells in the developing rat gut. 


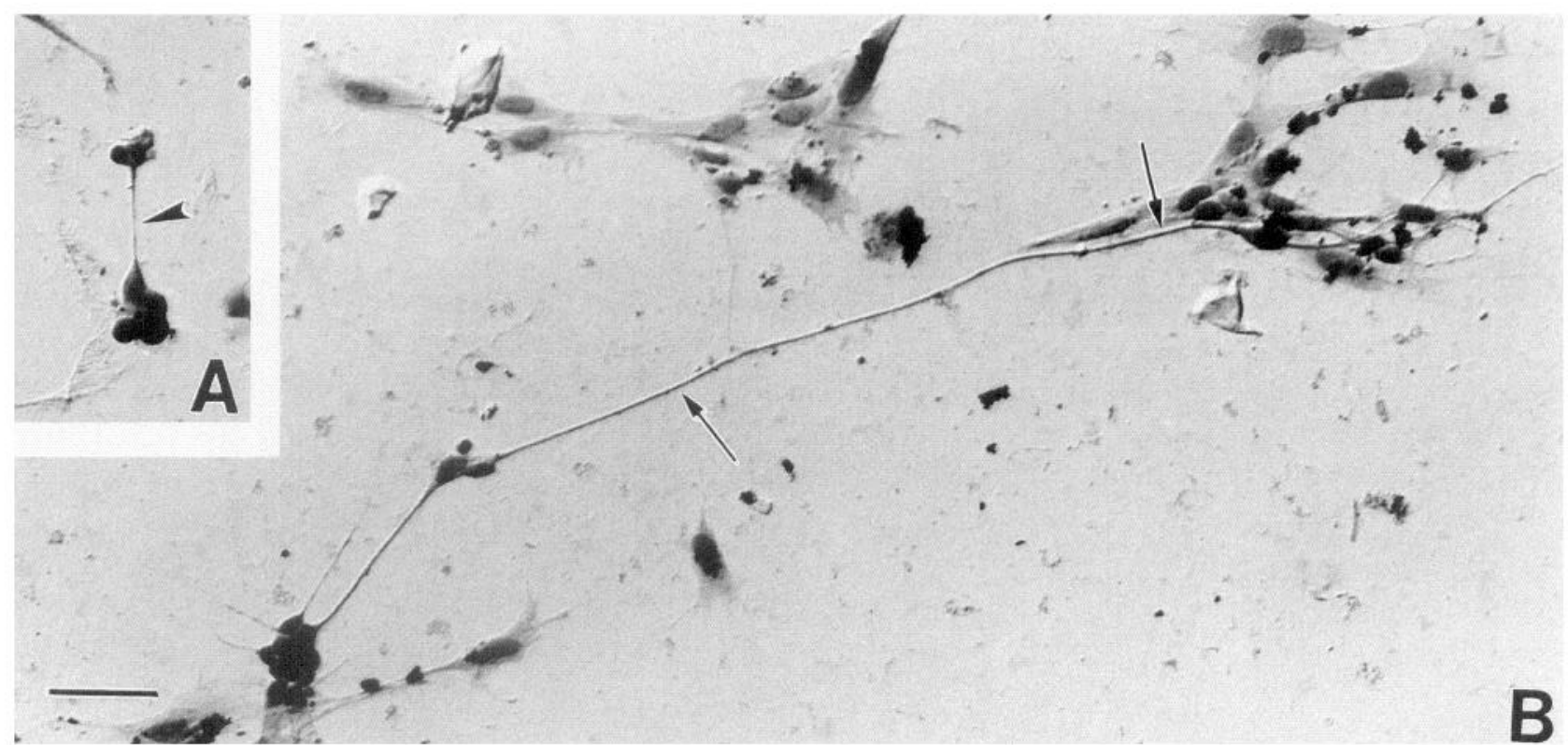

Figure 5. NT-3 enhances neurite outgrowth. $A$, Control culture neurofilament immunoreactivity. Most of the neurites are short and, in some cells, neurofilament immunoreactivity is confined to the cell body (arrowhead). B, NT-3-treated culture. Long neurofilament-immunoreactive processes are abundant and often establish interconnecting networks between clusters of neurons (arrows). Scale bar, $50 \mu \mathrm{m}$.

\section{$N T-3$ does not increase the proliferation of selected or unselected cells}

The NT-3-induced increase in the proportion of neurons and glia developing in vitro could, in theory, have been induced either by an action of NT-3 on the differentiation of precursors or by an action on their proliferation. NT-3 has been demonstrated to exert a mitogenic effect on premigratory crest cells (Kalcheim et al., 1992). In order to distinguish between these possibilities, the mitogenic potential of NT-3 was assessed. Im- munoselected and residual cultures were grown in defined medium with or without NT-3 for $3 \mathrm{~d}$. BrdU $(10 \mu \mathrm{M})$ was then added and the cultures were incubated for a further $24 \mathrm{hr}$. The BrdU-containing medium was then replaced with fresh medium and the control and NT-3-treated cultures were maintained for an additional $2 \mathrm{~d}$ (in the absence or presence, respectively, of NT-3) to permit terminally differentiated phenotypes to be expressed. Terminally differentiated neurons or glia that developed from precursors that were in the $\mathrm{S}$ phase of the cell cycle at any time during the $24 \mathrm{hr}$ when BrdU was present are doubly

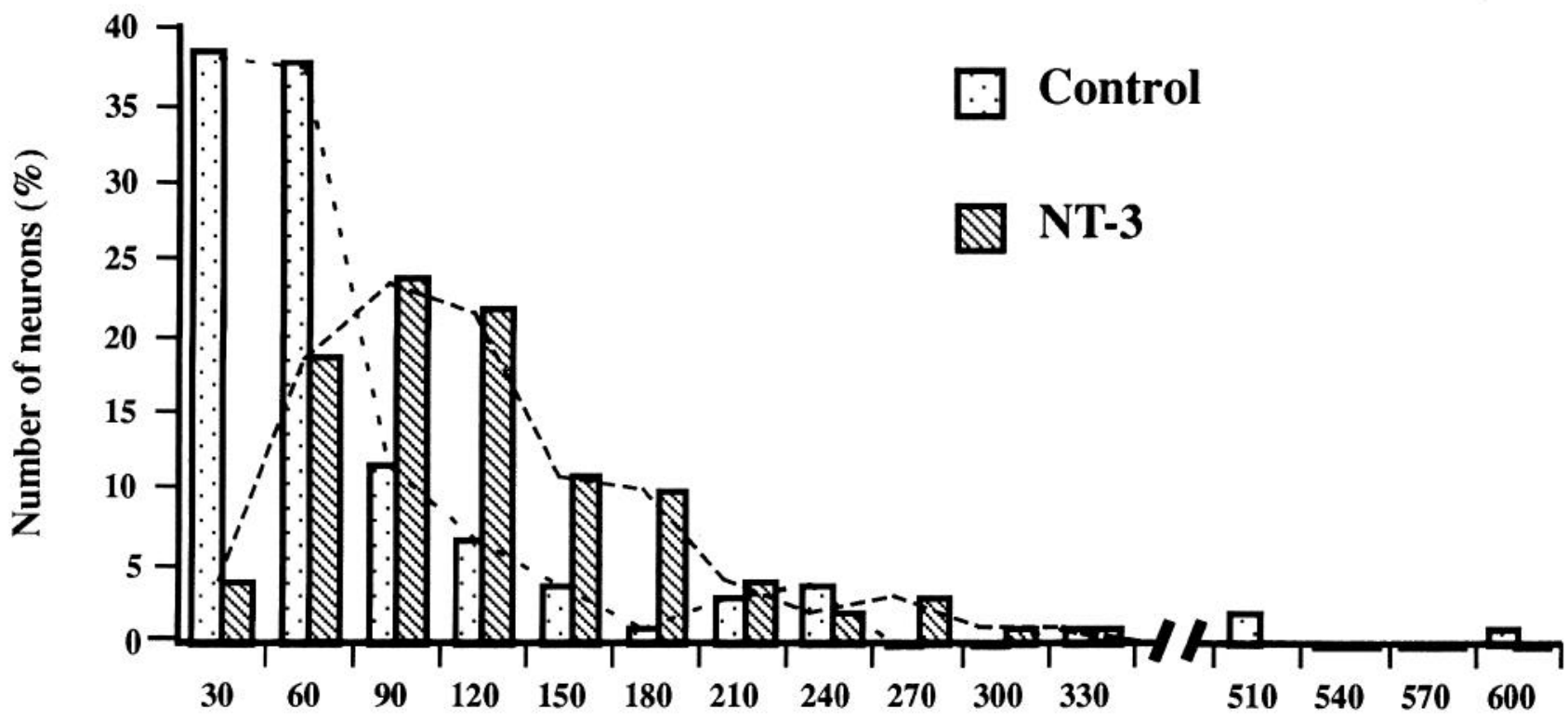

\section{Neurite length $(\mu \mathrm{m})$}

Figure 6. A greater proportion of the neurons extend long neurites in NT-3-treated than in control cultures. The proportion of neurons extending neurites of different lengths is shown as a histogram. The bin size for neurite length is $30 \mu \mathrm{m}$. 

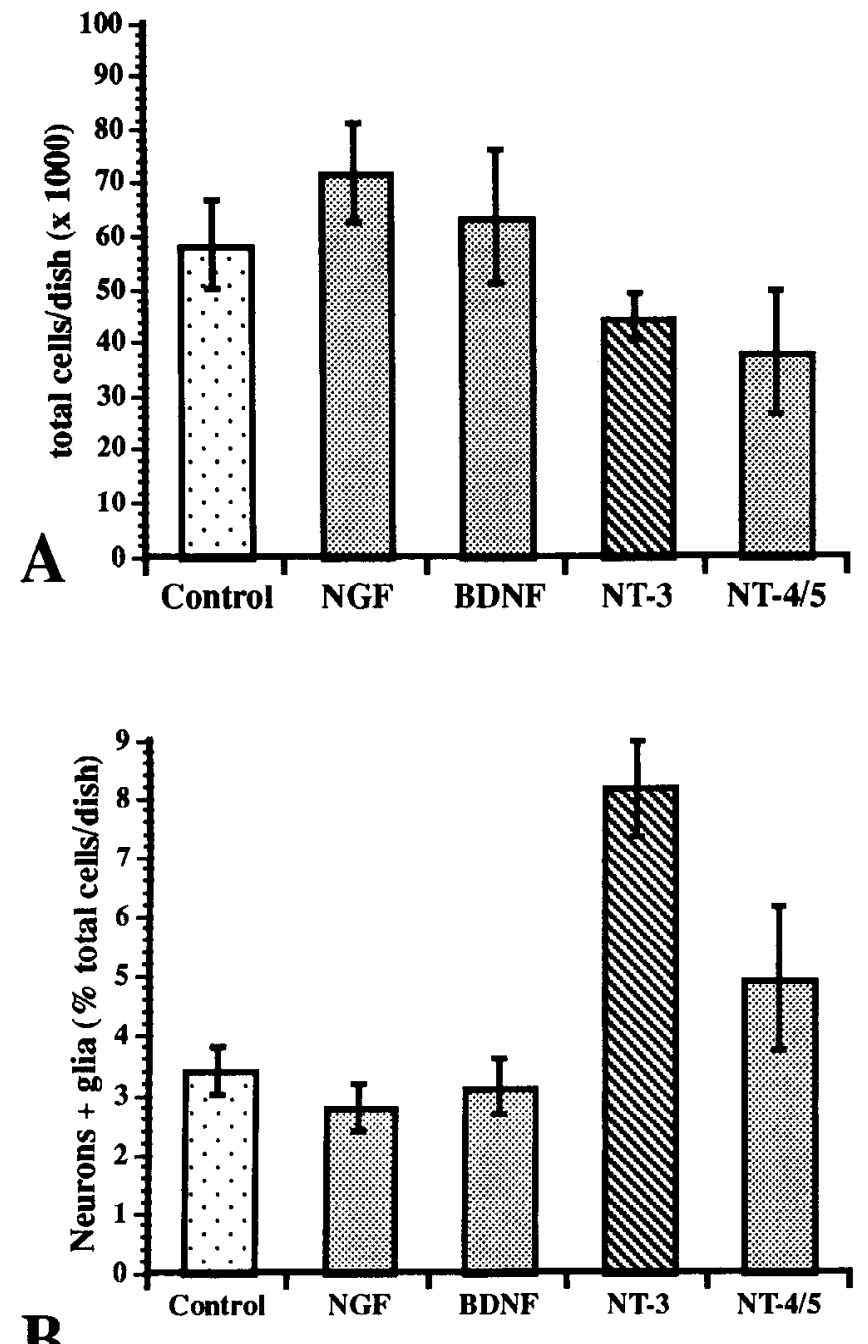

Figure 7. NT-3 is the only neurotrophin that increases the proportion of neurons and glia developing in vitro. Immunoselected cultures were maintained in the presence of each of the neurotrophins $(50 \mathrm{ng} / \mathrm{ml})$ for 1 week. The bars indicate means and the error bars the SE. $A$, Total cell numbers were unchanged by any of the neurotrophins. $B$, The proportion of neurons and glia (as percentage of total cells/dish) in the same cultures is increased by NT-3, but not by any of the other neurotrophins. Control, $n=8 ; N G F, n=4 ; B D N F, n=4 ; N T-3, n=10 ; N T-4 / 5, n$ $=3$.

labeled by antibodies to BrdU and NSE or S-100, respectively. As previously observed, the total number of cells in immunoselected (Fig. $8 A$ ) as well as residual cultures (Fig. $8 D$ ) was again comparable in control and NT-3-treated cultures. The ratio of cells doubly labeled by antibodies to BrdU and NSE to the total number of NSE-immunoreactive cells was unchanged by NT-3 in both immunoselected (Fig. $8 B$ ) and residual cultures (data not shown). Similarly, the ratio of cells doubly labeled by antibodies to BrdU and S-100 to the total number of S-100-immunoreactive cells was also unchanged by NT-3 in immunoselected (Fig. 8C) and residual cultures (data not shown). Interestingly, in the immunoselected cultures the ratio of BrdUlabeled glia:total glia $(0.6 \pm 0.1 ; n=4$ cultures $)$ was significantly higher than the ratio of BrdU-labeled neurons:total neurons $(0.3$ $\pm 0.1 ; n=3$ cultures; $p<0.05$ ) (compare Fig. $8, B$ with $C$ ). These results thus suggest that the increase in neuronal and glial development that occurs in response to NT-3 is not a mitogenic effect, but is due to an increase either in their differentiation from precursor cells or to their survival following differentiation.

Despite the fact that equal numbers of cells were plated in each culture dish, the total number of cells present in cultures of residual cells was always far higher than that in cultures of immunoselected cells (Fig. $8 D$ ). This difference ( $\sim 3.5$-fold) was unaffected by the addition of NT-3 to either type of culture. These observations suggest that the mesoderm-derived components of the enteric mesenchyme, which predominate in the cultures of residual cells, proliferate in vitro to a greater extent than do the crest-derived cells obtained by immunoselection.

\section{trkC is expressed in the fetal rat gut and by immunoselected cells}

NT-3 can bind to more than one neurotrophin receptor in nonneuronal cells (Cordon-Cardo et al., 1991; Klein et al., 1991b; Lamballe et al., 1991; Soppet et al., 1991; Squinto et al., 1991); however, its high-affinity receptor, which is thought to be physiologically responsible for mediating its neurotrophic properties, has been identified as gp 145 ${ }^{\text {rkc }}$ (Lamballe et al., 1991; Ip et al., $1993 b)$. We therefore utilized RT-PCR to investigate the expression of $t r k \mathrm{C}$ in the developing bowel. Total RNA and polyA+ RNA were extracted from preparations of whole gut at E14 and E16 and from $5.7 \times 10^{6}$ immunoselected or residual cells at E14. The amplimers for PCR were selected to encompass a part of the tyrosine kinase catalytic domain of gp $145^{t r k C}$. Specifically, the sct of amplimcrs (FL52-1 and FL53-1) were designed to amplify the sequence between bp 2074 and 2258 of porcine $t r k \mathrm{C}$ and would also be expected to amplify the corresponding sequence of rat $t r k C$, between bp 2043 and 2344 (Valenzuela et al., 1993). mRNA encoding gp 145 ${ }^{\text {trk }}$ was detected at E14 (data not shown) and E16 in the whole rat bowel when polyA ${ }^{+}$ RNA was used for RT-PCR (Fig. 9). Only a weak signal was obtained when total RNA was substituted for polyA ${ }^{+}$RNA (see Fig. 9, lane $\mathrm{Br}$ ). The major PCR product was found to migrate as a $184 \mathrm{bp}$ DNA fragment on agarose gels, suggesting that it is the isoform of $t r k \mathrm{C}$ that lacks an insert. A minor PCR product was also detected that had a mobility corresponding to a DNA fragment of $259 \mathrm{bp}$, suggesting that it corresponds to sequences encoding part of the TrkC K3 receptor, an isoform that contains a 25 amino acid insert located in the catalytic tyrosine kinase domain (Lamballe et al., 1993). Other previously described alternative forms of TrkC (Lamballe ct al., 1993; Tsoulfas et al., 1993; Valenzuela et al., 1993) were not detected. Immunoselected cells and residual cells isolated from the E14 fetal rat also contained trkC transcripts that could be demonstrated by RTPCR with extracted polyA ${ }^{+}$RNA. The size of these transcripts was again $184 \mathrm{bp}$ and $259 \mathrm{bp}$ (Fig. 9). The identity of the PCR products was confirmed by repeating RT-PCR using pFL35 with amplimers that corresponded to sequences (2097-2116 and 2301-2281) of rat $t r k C$ (Valenzuela et al., 1993) that lie within the PCR product amplified by the original primers. This smaller product was labeled with ${ }^{32} \mathrm{P}$-dCTP by random priming. The ${ }^{32} \mathrm{P}$-labeled smaller PCR product hybridized in Southern blots with the original larger PCR product, indicating that the same sequence had been amplified by both sets of primers.

\section{Discussion}

The present study was undertaken to determine whether onc of the factors in the enteric microenvironment that influence the differentiation of crest-derived cells in the wall of the bowel could be a neurotrophin. Although the neurotrophins bind to 

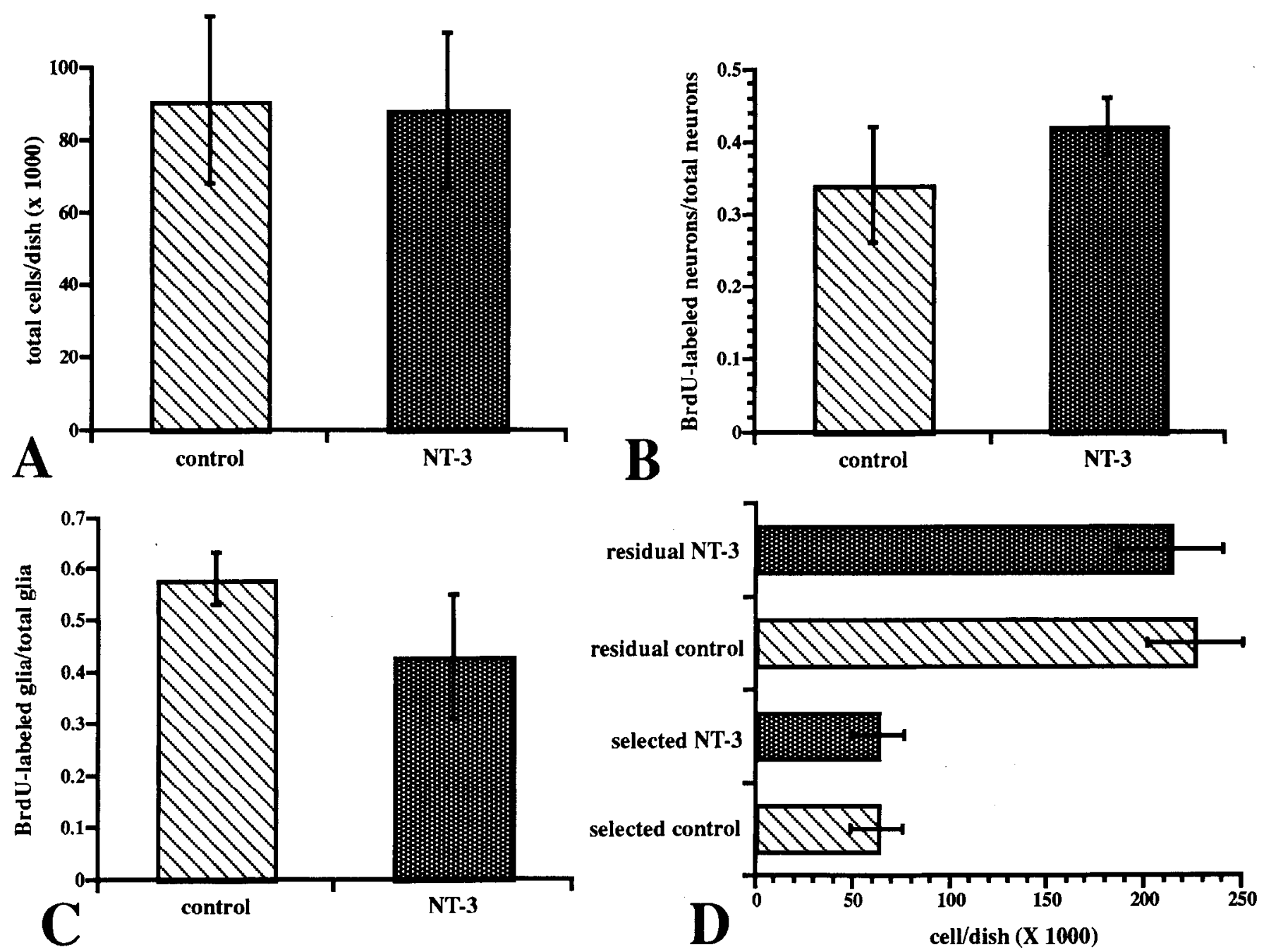

Figure 8. NT-3 does not exert a mitogenic effect on immunoselected or residual cells. $A-C$, Immunoselected cells cultured for 7 d. The data were pooled from two separate experiments. $A$, Total number of cells. Control, $n=7 ; N T-3, n=9$. B, Proportion of neurons developing from precursors that were in the $S$ phase of the cell cycle on day 3 in vitro. Double-label immunocytochemistry was carried out to detect BrdU incorporation in NSE-immunoreactive neurons. Control, $n=3 ; N T-3, n=5$. C, Proportion of glia developing from precursors that were in the $S$ phase of the cell cycle on day 3 in vitro. Double-label immunocytochemistry was carried out to detect BrdU incorporation in S-100-immunoreactive glia. Control, $n=4 ; N T-3, n=4$. D. Comparison of total numbers of cells in cultures of immunoselected versus residual cells in the absence or presence of NT-3 $(40 \mathrm{ng} / \mathrm{ml})$. The data were pooled from four separate experiments. Residual cells proliferate to a greater extent than do immunoselected cells; however, the proliferation of neither is affected by NT-3.

gp75 $5^{\text {LNGFR }}$ with low affinity (Rodriguez-Tébar et al., 1992), the effects of the neurotrophins are mediated by members of the Trk family of receptor tyrosine kinases (Meakin and Shooter, 1991; Barbacid, 1993). The trkA proto-oncogene encodes gp 140 ${ }^{r k A}$, the functional receptor for NGF (Hempstead et al., 1991; Kaplan et al., 1991; Klein et al., 1991a). The functional receptor for BDNF and NT-4/5, gp $145^{r r k \mathrm{~B}}$, is encoded by $\operatorname{trkB}$ (Berkemeier et al., 1991; Klein et al., 1991 b; Soppet et al., 1991; Squinto et al., 1991; Ip et al., 1993b). Finally, the related gp $145^{\text {trkc }}$, encoded by the $t r k \mathrm{C}$ gene, is the transducing receptor for NT-3 (Lamballe et al., 1991). Testing the role of a neurotrophin, therefore, involves both determining the actions of these factors on enteric neuronal development and evaluating the expression of members of the Trk receptor family. An in vitro approach was used, in which the effects of neurotrophins were analyzed on separated populations of cells from dissociated fetal rat bowel that were either enriched or impoverished in crest-derived cells by immunoselection. The results of these experiments suggest that the crest-derived cells that colonize the fetal bowel respond specifically to NT-3, which in a concentration-dependent manner transiently induces expression of $c$-fos, enhances thcir dcvelopment as neurons and glia, and stimulates neurite outgrowth. Since the action of NT-3 begins to diminish at supramaximal concentrations, it is possible that high NT- 3 concentrations are toxic or induce the internalization of TrkC, thereby diminishing its effectiveness. Responsiveness to EGF, for example, decreases following prolonged exposure of cells to this growth factor because EGF receptors are internalized (Massagué, 1983) and TrkA is internalized following exposure to high concentrations of NGF (Levi et al., 1988). No effects of NT -3 could be detected in the residual cells, most of which were not crest derived, and no effects of other neurotrophins on the crest-derived cells were observed. Since NT-3 was not found to exert a mitogenic effect on any of the enteric cells in vitro, the action of this neurotrophin appears to induce crest-derived cells to differentiate (and/or survive) as neurons and/or glia, rather than to stimulate the proliferation of the precursors of these cells. The idea that NT-3 affects the development of enteric 


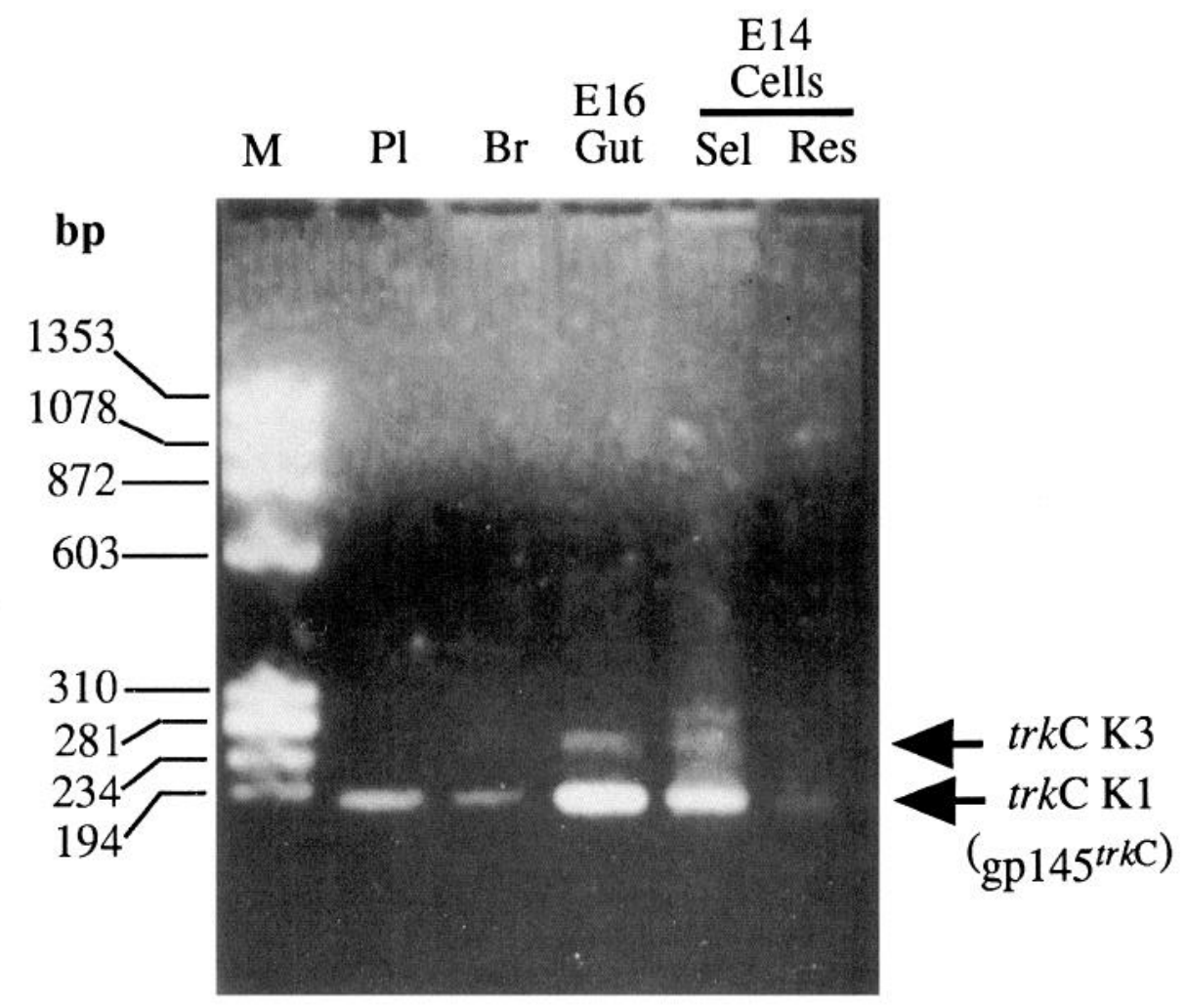

Figure 9. Expression of $t r k \mathrm{C}$ transcripts is detected in the developing rat gut and in the population of cells immunoselected by HNK-1/NC-1: ethidium bromide-stained $2 \%$ agarose gel containing PCR-amplified DNAs from the plasmid pFL35, which contains cDNA encoding the tyrosine kinase domain of mouse TrkC $\mathrm{K} 1(\mathrm{Pl})$; adult rat brain $(B r)$; intact fetal rat bowel (E16 $G u t)$; and acutely dissociated cells from fetal gut $(E 14$ cells $)$ that were either HNK-1/NC-1 immunoselected $(\mathrm{Sel})$ or the residual population of unselected cells (Res). Lane $M$, size markers. The arrow at trk $C K 3$ indicates the migration of PCR products that correspond to the $259 \mathrm{bp}$ amplified fragment of the TrkC K3 isoform. The arrow at trk $C$ $K I$ indicates PCR products representing sequences of the TrkC K1 receptor. Note that nearly equal amounts of polyA + RNA from the samples of immunoselected and residual cells were subjected to RT-PCR. Total RNA was analyzed from brain.

neurons and glia was further supported by the detection of transcripts encoding TrkC, the functional receptor for NT-3 (Lamballe et al., 1991; Ip et al., 1993b), in the fetal rat bowel during the time (E14-E16) when the intrinsic ganglia of the ENS are formed (Baetge et al., 1990a), and in the immunoselected population of crest-derived cells that responded to NT-3.

The immunoselection procedure that was used to obtain crestderived cells took advantage of the fact that such cells are the only ones in the fetal bowel that express an epitope recognized by the NC-1 (Baetge et al., 1990a) or HNK-1 monoclonal antibodies (which recognize the same epitope) (Tucker et al., 1984). In avian embryos, this carbohydrate antigen is expressed early in development only by migrating crest-derived cells and by those differentiating as neurons and glia (Vincent et al., 1983; Vincent and Thiery, 1984; Tucker et al., 1988). The same epitope is expressed with equal specificity during development in fetal rats (Erickson et al., 1989). The immunoselection procedure, therefore, in utilizing NC-1 would be expected to lead to the enrichment only of those cells that are of neural crest origin. On the other hand, subsets of rat crest-derived cells are not NC1/HNK-1 immunoreactive (Bannerman and Pleasure, 1993), while avian crest-derived cells lose NC-1 immunoreactivity when they develop in vivo as mesectoderm or melanocytes (Vincent and Thiery, 1984; Tucker et al., 1988), and during growth in vitro when they fail to acquire a neural or a glial phenotype (Maxwell et al., 1988; Maxwell and Forbes, 1991). These considerations imply that some of the crest-derived cells of the fetal bowel might have escaped selection with the $\mathrm{NC}-1$ reagent if they had ceased to express this antigen at the time (E14) of immunoselection. Such cells, as well as some NC-1-immunoreactive cells that might not have been immunoselected because of procedural inefficiencies, could account for the small number of neurons and glia in the cultures of unselected (residual) cells.
After plating, furthermore, many of the cells of the immunoselected population probably lose their NC-1 immunoreactivity during their subsequent growth in vitro. As a result, measurements of the efficiency of immunoselection, which depended on the detection of cells in the cultures that were NC-1 immunoreactive, probably provided underestimates of the degree to which the cultures were actually enriched in cells of neural crest origin. Even so, a 36-fold enrichment was found, indicating that the procedure was highly effective. The additional observations that the unselected (residual) cells survived better after initial plating and proliferated in culture far more (more than threefold) than did those that were immunoselected, and that NT-3 affected the immunoselected, but not the unselected cells, confirmed that the two populations are quite different. The crestderived contaminants of cultures of unselected cells would be expected to thrive relatively well in vitro, even in the absence of an exogenous critical growth/differentiation factor. In contrast to their counterparts in immunoselected cultures, the crestderived contaminants are likely to be the beneficiaries of trophic effects exerted by their more abundant non-neuronal neighbors. This idea is supported by the relatively poor initial survival of the immunoselected cells, which probably are detrimentally affected by the withdrawal of support from mesenchymal cells. Secretion of NT-3 by non-neuronal cells, for example, could be the reason why even the crest-derived contaminants in the cultures of residual cells apparently failed to respond to exogenous NT-3. It is also possible that subpopulations of neuronal and glial precursors exist that are not responsive to NT-3 or that some precursors become committed to neuronal or glial phenotypes prior to the time of immunoselection.

It was initially assumed, on the basis of immunocytochemical observations with neural crest markers (Baetge et al., 1990a), that the crest-derived population would represent $\sim 10 \%$ of the 
cells of the dissociated E14 rat gut. Calculation of the yield of cells immunoselected with $\mathrm{NC}-1$ indicated that on average, from experiment to experiment, $\sim 10 \%$ of the original dissociated cell population was indeed selected by the NC-1 reagent. Interestingly, although neural and glial development was greater in the cultures of NC-1-immunoselected cells than in the cultures of cells left behind, particularly following exposure to NT-3, in no instance did neurons and glia constitute the majority of cells in any of the cultures. The non-neuronal cells that did not become glia assumed a typical mesenchymal morphology and, after 1 week in vitro, were not NC-1 immunoreactive. It is known that non-neuronal cells with a mesenchymal morphology do develop from NC-1-immunoreactive cells in cultures of fetal mouse bowel (Coulter et al., 1988). It is possible that some (or all) of the mesenchyme-like cells in immunoselected cultures developed from crest-derived precursors that lost their original NC-1 immunoreactivity. Alternatively, some may represent non-crestderived cells that bound nonspecifically to the beads used for immunoselection. Estimates of the proportion of cells subject to nonspecific selection, made by omitting primary antibodies, suggested that such cells were $<25 \%$ of the immunoselected population. It seems likely, therefore, that the majority of the immunoselected crest-derived cell population simply failed to develop in vitro as neurons or glia. This failure suggests that additional factors, besides NT-3, which influence enteric neural and glial development in vivo, may not be present in either the defined or serum-containing medium utilized in the present in vitro experiments. A further consideration, however, is that the extent to which crest-derived cells in vivo contribute to nonneuronal supporting cells of the ENS, other than glia, has never been ascertained. The question is difficult to answer, because the non-neuronal cells lose their neural crest markers during development. This issue is particularly intriguing with respect to a group of enteric cells that function in concert with the ENS in the control of gastrointestinal motility, the interstitial cells of Cajal (Langton et al., 1989; Prosser et al., 1989; Thuneberg, 1989; Serio et al., 1991). These cells are thought to be responsible for the generation of pacemaker potentials and intestinal slow waves; nevertheless, their embryonic derivation has not yet been established. Conceivably, interstitial cells of Cajal may be crest derived, and if so could contribute to the unidentified cells of the immunoselected cultures. Because a marker is lacking, an effect of NT-3 on development of interstitial cclls would not have been detected.

NT-3 has been shown to exert a mitogenic effect on the primary crest-derived cells that migrate away from explants of truncal neural tube in vitro (Kalcheim et al., 1992). Interestingly, NT-3 exerts its action on these primary crest cells only when they are grown on a cellular substrate and not when they are cultured on laminin (Pinco et al., 1993). The responsiveness of crest-derived cells to NT-3, therefore, changes as the cells mature. This change evidently occurs either between the time these cells leave the neuraxis and the time they arrive in the bowel or soon after they colonize the gut. NT-3 increased neither the total number of cells in enteric cultures, nor the in vitro incorporation of BrdU by the immunoselected crest-derived precursors of enteric neurons or glia. This difference in responsiveness to NT-3 is one of several changes that take place in the crestderived population during its migration to the bowel. Others include the acquisition of LBP1 10 (Pomeranz et al., 1991b), and the loss of the ability to express a melanocytic phenotype (Coulter et al., 1988; Rothman et al., 1990, 1993). These changes could be the result of age or responses to factors encountered by the cells as they migrate, and illustrate why investigations of the role of growth/differentiation factors in the development of the ENS must utilize crest-derived cells isolated from within the bowel. Our observation that NT-3 does not have a mitogenic effect on differentiating enteric cells is consistent with the possibility that NT-3 induces crest-derived cells to differentiate along neural and/or glial lineages. It is also possible that NT-3 enhances survival of these cells. Our experiments did not distinguish between these two possibilities. NT-3, which is not a mitogen for dividing sympathetic ncuroblasts, neverthcless enhances their survival (Birren et al., 1993; DiCicco-Bloom et al., 1993). The fact that NT-3 simultaneously increased the development of both enteric neurons and glia makes it impossible to conclude which of these lineages is the primary target of NT-3. By promoting the development of neurons, NT-3 might have indirectly enhanced the differentiation of glia. The converse could also be true. Clearly, in order to distinguish between these latter two possibilities, it will be necessary to develop means of separating the precursors of enteric neurons and glia.

The ability of NT-3 to enhance the extension of neurites by enteric neurons in culture is reminiscent of its previously described action on the outgrowth of neurites from explants of Remak's ganglia from chick embryos (Ernfors et al., 1990). Like the ENS proper, Remak's ganglion is derived from the neural crest; moreover, some of the crest-derived émigrés that give rise to Remak's ganglion come from the same axial level (the sacral) as do crest-derived cells that colonize the hindgut (Teillet, 1978; Pomeranz and Gershon, 1990; Pomeranz et al., 1991a; Serbedzija et al., 1991). This observation thus suggests that NT-3 may be an important growth/differentiation factor for neurons related to those of the ENS. It is of particular interest that cells that give rise to a peripheral glial cell (those demonstrated by S-100 immunoreactivily) are also responsive to NT-3. Effects of NT-3 on optic nerve glial precursors have recently been described (Barres et al., 1994). Another marker that was expressed by immunoselected cells in vitro was $\mathrm{O} 4$, which is a characteristic of Schwann cells and oligodendroglia (Mirsky et al., 1990; Jessen and Mirsky, 1992). Oligodendrocytes are never found in the ENS. Interestingly, in contrast to $\mathrm{S}-100$, which is a marker for enteric glia (Bishop et al., 1985; Kobayashi et al., 1986; Scheuermann et al., 1989), expression of the O4 epitope was not significantly increased by NT-3. Enteric glia, which are different from Schwann cells (Gershon and Rothman, 1991), develop from the original wave of crest-derived precursors that colonizes the bowel and not from cells that enter the gut along with the ingrowing extrinsic innervation (Rothman et al., 1986). In avians, enteric glia acquire Schwann cell markers when these cells are experimentally removed from the gut (Dulac et al., 1988; Dulac and Le Douarin, 1991). The expression of the O4 antigen by crest-derived cells isolated from the rat gut may thus be a manifestation of a Schwann-like phenotype by crest-derived cells developing outside the enteric microenvironment. The relative nonresponsiveness of such cells to NT-3, therefore, may be a reflection of their differentiation along a nonenteric lineage.

The rapid and transient expression of $c$-fos that was induced by NT-3 is similar to the known actions of many growth factors on a variety of cell types both in vitro and in vivo (Curran and Morgan, 1985; Greenberg et al., 1985; Condorelli et al., 1989; Sagar et al., 1991). Neurotrophin-responsive hippocampal neurons have also been found to become transiently Fos immunoreactive (with one of the antibodies to Fos used in the present 
study) when they are exposed to BDNF, NT-3, or NT-4/5 in vitro (Ip et al., 1993a). The Fos-immunoreactive cells that were seen in cultures exposed to NT-3 were usually found in clusters and often exhibited processes of variable length. The large flat cells with a mesenchymal appearance were never Fos immunoreactive. The proportion of cells that exhibited Fos immunoreactivity $(\sim 18 \%)$ within $1-2 \mathrm{hr}$ of exposure to NT-3 was similar to the proportion of cells in NT-3-treated cultures of immunoselected cells that differentiated as neurons and glia $(\sim 15 \%)$. The relatively close agreement of these percentages suggests that the cells that transiently express $c$-fos soon after the addition of NT-3 are the same cells that later develop as neurons and glia. RT-PCR analyses show that transcripts encoding TrkC are present in cultures of immunoselected cells. These results suggest that NT-3 activates enteric crest-derived cells through functional TrkC receptor(s). The amplimers used in this study were selected to amplify sequences encoding part of the tyrosine kinase catalytic domain of gp145 $15^{r k c}$. The amplified DNA fragments correspond to sequences coding for two TrkC catalytic isoforms, $\mathrm{K} 1$ and $\mathrm{K} 3$, that are able to transduce signals to the nucleus (Lamballe et al., 1993).

The specificity of the neurotrophin responsiveness of enteric crest-derived cells is noteworthy. These cells responded well to NT-3, but we did not detect responses to NGF, BDNF, or NT$4 / 5$. In this respect the enteric crest-derived cells differ from other crest-derived cell populations. For example, BDNF and NGF promote the development of primary afferent neurons in cultures of crest cells obtained by migration away from the neural tube (Sieber-Blum, 1991). Growth/differentiation factors can also have effects in combinations or when added sequentially that are different from those of the same factors applied individually. Neurotrophin responsiveness, therefore, may be influenced by the prior exposure of cells to a different factor; for example, an initial exposure of cells to bFGF may be necessary to induce sympathoadrenal precursors to acquire a neuronal phenotype and to become NGF dependent (Stemple et al., 1988; Birren and Anderson, 1990). The present data thus do not preclude the possibility that enteric neural and/or glial precursors may behave differently with respect to the neurotrophins examined if factors other than those that were present in our medium were to be added.

While the present observations strongly suggest that NT-3 may play an important physiological role in the development of the ENS, additional evidence is still needed to prove that the action of NT-3 is critical. The presence of mRNA encoding NT3 , but not that encoding either NGF or BDNF, has been shown in the rat and mouse bowel (Hohn et al., 1990; Maisonpierre et al., 1990); furthermore, immunocytochemical evidence for the expression of NT-3 in the mucosal epithelium of the fetal (Scarisbrick et al., 1993) and adult (Zhou and Rush, 1993) rat gut has recently been reported. Still needed, however, is a systematic study detailing which cells in the fetal bowel synthesize and secrete NT-3 and whether they do so at the time when enteric neurons and glia differentiate. Also needed is a reagent that specifically blocks the effects of NT-3 during development. If NT-3 is absolutely required in the development of the ENS, then such a reagent would be expected to prevent the development of enteric neurons or glia. Finally, although available evidence suggests that only trkC (Tessarolo et al., 1993; Tsoulfas et al., 1993; Lamballe et al., 1994), and not trkA (Martin-Zanca et al., 1990; Barbacid, 1993) or trkB (Klein et al., 1990), is expressed in the developing bowel, the possibility that small subsets of cells may become responsive to neurotrophins other than NT-3 has not rigorously been excluded. The present study of NT-3, however, is the first to implicate a neurotrophin in the formation of the ENS.

\section{References}

Baetge G, Pintar JE, Gershon MD (1990a) Transiently catecholaminergic (TC) cells in the bowel of fetal rats and mice: precursors of noncatecholaminergic enteric neurons. Dev Biol 141:353-380.

Baetge G, Schneider KA, Gershon MD (1990b) Development and persistence of catecholaminergic neurons in cultured explants of fetal murine vagus nerves and bowel. Development 110:689-701.

Bannerman PG, Pleasure DE (1993) The monoclonal antibody HNK-1 marks geographically restricted subsets of rat neural crest cells. Soc Neurosci Abstr 19:861.

Barbacid M (1993) The $t r k$ family of ncurotrophin receptors: molecular characterization and oncogenic activation in human tumors. In: Molecular genetics of nervous system tumors (Levine AJ, Schmidek HH, eds), pp 123-135. New York: Wiley.

Barres BA, Raff MC, Gaese F, Bartke I, Dechant G, Barde Y-A (1994) A crucial role for neurotrophin-3 in oligodendrocyte development. Nature 367:371-375.

Berkemeier LR, Winslow JW, Kaplan DR, Nikolics K, Goeddel DV, Rosenthal A (1991) Neurotrophin-5: a novel neurotrophic factor that activates trk and trk $B$. Neuron 7:857-866.

Birren SJ, Anderson DJ (1990) A v-myc immortalized sympathoadrenal progenitor cell line in which neuronal differentiation is initiated by FGF but not NGF. Neuron 4:189-201.

Birren SJ, Lo L, Anderson DJ (1993) Sympathetic neuroblasts undergo a developmental switch in trophic dependence. Development 119: 597-610.

Bishop AE, Carlie F, Lee V, Trojanowski J, Marangos PJ, Dahl D, Polak JM (1985) Combined immunostaining of neurofilaments, neuron specific enolase, GFAP, and S-100. A possible method for assessing the morphological and functional status of the enteric nervous system. Histochemistry 82:93-97.

Brazeau P, Ling N, Esch F, Böhlen P, Benoit R, Guillemin R (1981) High biological activity of the synthetic replicates of somatostatin28 and somatostatin-25. Regul Pept 1:225-264.

Carnahan JF, Anderson DJ, Patterson PH (1991) Evidence that enteric neurons may derive from the sympathoadrenal lineage. Dev Biol 148: 552-561.

Chalazonitis A, Kessler JA, Twardzik DR, Morrison RS (1992) Transforming growth factor $\alpha$, but not cpidcrmal growth factor, promotes the survival of sensory neurons in vitro. J Neurosci 12:583-594.

Chalazonitis A, Rothman TP, Gershon MD (1993) Neurotrophin-3 promotes neuronal and glial differentiation in cultured neural crestderived cells from fetal rat gut. Soc Neurosci Abstr 19:417.

Chandler CE, Parsons LM, Hosang M, Shooter EM (1984) A monoclonal antibody modulates the interaction of nerve growth factor with PC1 2 cells. J Biol Chem 259:6882-6889.

Chomczynski P, Sacchi N (1987) Single-step method of RNA isolation by acid guanidinium thiocyanate-phenol-chloroform extraction. Anal Biochem 162:156-159.

Condorelli D, Kaczmarek L, Nicoletti F, Arcidiacono Dell'Albani P (1989) Induction of proto-oncogene fos by extracellular signals in primary glial cell cultures. J Neurosci Res 23:234-239.

Cordon-Cardo C, Tapley P, Jing S, Nanduri V, O'Rourke E, Lamballe F, Kovary K, Klein R, Jones KR, Reichardt LF, Barbacid M (1991) The trk tyrosine protein kinase mediates the mitogenic properties of nerve growth factor and neurotrophin-3. Cell 66:173-183.

Coulter HD, Gershon MD, Rothman TP (1988) Neural and glial phenotypic expression by neural crest cells in culture: effects of control and presumptive aganglionic bowel from ls/ls mice. J Neurobiol 19: 507-531.

Curran T, Morgan II (1985) Superinduction of $c$-fos by nerve growth factor in the presence of peripherally active benzodiazepines. Science 229:1265-1268

DiCicco-Bloom E, Friedman WJ, Black IB (1993) NT-3 stimulates sympathetic neuroblast proliferation by promoting precursor survival. Neuron 11:1101-1111.

DiStefano PS, Friedman B, Radziejewski C, Alexander C, Boland P, Schick CM, Lindsay RM, Wiegand SJ (1992) The neurotrophins 
BDNF, NT-3, and NGF display distinct patterns of retrograde axonal transport in peripheral and central neurons. Neuron 8:983-993.

Dreyfus CF, Sherman D, Gershon MD (1977) Uptake of serotonin by intrinsic neurons of the myenteric plexus grown in organotypic tissue culture. Brain Res 128:109-123.

Dulac C, Le Douarin NM (1991) Phenotypic plasticity of Schwann cells and enteric glial cells in response to the microenvironment. Proc Natl Acad Sci USA 88:6358-6362.

Dulac C, Cameron-Curry P, Ziller C, Le Douarin NM (1988) A surface protein expressed by avian myelinating and non myelinating Schwann cells but not by satellite or enteric glial cells. Neuron 1:211-220.

Erickson CA, Loring JF, Lester SM (1989) Migratory pathways of HNK-1-immunoreactive neural crest cells in the rat embryo. Dev Biol 134:112-118.

Ernfors P, Ibanez CF, Ebendal T, Olson L, Persson H (1990) Molecular cloning and neurotrophic activities of a protein with structural similarities to nerve growth factor: developmental and topographical expression in the brain. Proc Natl Acad Sci USA 87:5454-5458.

Gershon MD, Rothman TP (1991) Enteric glia. Glia 4:195-204.

Greenberg ME, Greene LA, Ziff EB (1985) Nerve growth factor and epidermal growth factor induce rapid transient changes in proto-oncogene transcription in PC12 cells. J Biol Chem 260:14101-14110.

Hallböök F, Ibanez CF, Persson H (1991) Evolutionary studies of the nerve growth factor family reveal a novel member abundantly expressed in Xenopus ovary. Neuron 6:845-858.

Hempstead BL, Martin-Zanca D, Kaplan DR, Parada LF, Chao M (1991) High affinity NGF binding requires coexpression of the trk proto-oncogene and the low affinity NGF receptor. Nature 350:678693.

Hohn A, Leibrock J, Bailey J, Barde Y-A (1990) Identification and characterization of a novel member of the nerve growth factor/brainderived neurotrophic factor family. Nature 344:339-341.

Ip NY, Li Y, Yancopoulos GD, Lindsay RM (1993a) Cultured hippocampal neurons show responses to BDNF, NT-3, and NT-4, but not NGF. J Neurosci 13:3394-3405.

Ip NY, Stitt TN, Tapley P, Klein R, Glass DJ, Fandl J, Greene LA, Barbacid M, Yancopoulos GD (1993b) Similarities and differences in the way neurotrophins interact with the Trk receptors in neuronal and non neuronal cells. Neuron 10:137-149.

Jessen KR, Mirsky R (1992) Schwann cells: early lineage, regulation of proliferation, and control of myelin formation. Curr Opin Neurobiol 2:575-581.

Kalcheim C, Carmeli C, Rosenthal A (1992) Neurotrophin-3 is a mitogen for cultured neural crest cells. Proc Natl Acad Sci USA 89: 1661-1665.

Kaplan DR. Hempstead BL, Martin-Zanca D, Chao MV, Parada LF (1991) The trk proto-oncogene product: a signal transducing receptor for nerve growth factor. Science 252:554-558.

Kibbey MC, Jucker M, Weeks BS, Neve RL, VanNostrand WE, Kleinman HK (1993) $\beta$-Amyloid precursor protein binds to the neuritepromoting IKVAV site of laminin. Proc Natl Acad Sci USA 90: 10150-10153.

Klein R, Martin-Zanca D, Barbacid M, Parada LF (1990) Expression of the tyrosine kinase receptor gene trkB is confined to the murine embryonic and adult nervous system. Development 109:845-850.

Klein R, Jing S, Nanduri V, O'Rourke E, Barbacid M (1991a) The trk proto-oncogene encodes a receptor for nerve growth factor. Cell 65:189-197.

Klein R, Nanduri V, Jing S, Lamballe F, Tapley $P$, Bryant $S$, CordonCorado C, Jones KR, Reichardt LF, Barbacid M (1991b) The trkB protein kinase is a receptor for brain derived neurotrophic factor and neurotrophin-3. Cell 66:395-403.

Kleinman HK, Weeks BS, Cannon FB, Sweeney TM, Sephel GC, Clement B, Zain M, Olson MOJ, Jucker M, Burrous BA (1991) Identification of a $110 \mathrm{kDa}$ nonintegrin cell surface laminin-binding protein which recognizes an A chain neurite-promoting peptide. Arch Biochem Biophys 290:320-325.

Kobayashi S, Suzuki M, Endo T, Tsuji S, Daniel EE (1986) Framework of the enteric nerve plexuses: an immunocytochemical study in the guinea pig jejunum using an antiserum to S-100 protein. Arch Histol Jpn 49:159-188.

Lamballe F, Klein R, Barbacid M (1991) trkC, a new member of the trk family of tyrosine protein kinases, is a receptor for neurotrophin3. Cell 66:967-979.

Lamballe F, Tapley P, Barbacid M (1993) trkC encodes multiple neurotrophin-3 receptors with distinct biological properties and substrate specificities. EMBO J 12:3083-3094.

Lamballe F, Smeyne R, Barbacid M (1994) Developmental expression of trkC, the neurotrophin-3 receptor, in the mammalian nervous system. J Neurosci 14:14-28.

Langton P, Ward SM, Carl A, Norell MA, Sanders KM (1989) Spontaneous electrical activity of interstitial cells of Cajal isolated from canine proximal colon. Proc Natl Acad Sci USA 86:7280-7284.

Le Douarin NM (1982) The neural crest. Cambridge: Cambridge UP. Le Douarin NM, Teillet MA (1973) The migration of neural crest cells to the wall of the digestive tract in avian embryo. J Embryol Exp Morphol 30:31-48.

Le Douarin NM, Teillet MA (1974) Experimental analysis of the migration and differentiation of neuroblasts of the autonomic nervous system and of neuroectodermal mesenchymal derivatives, using a biological cell marking technique. Dev Biol 41:162-184.

Leibrock J, Lottspeich F, Hohn A, Hofer M, Hengerer B, Masiakowski P, Thoenen H, Barde Y-A (1989) Molecular cloning and expression of brain-derived neurotrophic factor. Nature 341:149-152.

Levi A, Biocca S, Cattaneo A, Calissano P (1988) The mode of action of nerve growth factor in PC12 cells. Mol Neurobiol 2:201-226.

Levi-Montalcini R (1987) The nerve growth factor thirty-five years later. Science 237:1154-1162.

Loeb DM, Maragos J, Martin-Zanca D, Chao M, Parada LF, Greene LA (1991) The trk proto-oncogene rescues NGF responsiveness in mutant NGF-non responsive PC12 cell lines. Cell 66:961-966.

Maisonpierre PC, Belluscio L, Squinto S, Ip NY, Furth ME, Lindsay RM, Yancopoulos GD (1990) Neurotrophin-3: a neurotrophic factor related to NGF and BDNF. Science 247:1446-1451.

Martin-Zanca D, Barbacid M, Parada LF (1990) Expression of the trk proto-oncogene is restricted to the sensory cranial and spinal ganglia of neural crest origin in mouse development. Genes Dev 4:683-694.

Massagué J (1983) Epidermal growth factor-like transforming growth factor: interaction with epidermal growth factor receptors in human placental membranes and A431 cells. J Biol Chem 258:3614-1362.

Maxwell GD, Forbes ME (1991) Spectrum of in vitro differentiation of quail trunk neural crest cells isolated by cell sorting using the HNK-1 antibody and analysis of the adrenergic development of HNK1+ sorted subpopulations. J Neurobiol 22:276-286.

Maxwell GD, Forbes ME, Christie DS (1988) Analysis of the development of cellular subsets present in the neural crest using cell sorting and cell culture. Neuron 1:557-568.

Meakin SO, Shooter EM (1991) Molecular investigation on the high affinity nerve growth factor receptor. Neuron 6:153-163.

Mirsky R, Dubois C, Morgan L, Jessen CR (1990) O4 and A007sulfatide antibodies bind to embryonic Schwann cells prior to the appearance of galactocerebrosides; regulation of the antigen by axonSchwann cell signals and cyclic AMP. Development 109:105-116.

Pinco O, Carmeli C, Rosenthal A, Kalcheim C (1993) Neurotrophin-3 affects proliferation and differentiation of distinct neural crest cells and is present in the early neural tube of avian embryos. J Neurobiol 24:1626-1641.

Pomeranz HD, Gershon MD (1990) Colonization of the avian hindgut by cells derived from the sacral neural crest. Dev Biol 137:378-394.

Pomeranz HD, Rothman TP, Gershon MD (1991a) Colonization of the post-umbilical bowel by cells derived from the sacral neural crest: direct tracing of cell migration using an intercalating probe and a replication-deficient retrovirus. Development 111:647-655.

Pomeranz HD, Sherman DL, Smalheiser NR, Tennyson VM, Gershon MD (1991b) Expression of a neurally related laminin binding protein by neural crest-derived cells that colonize the gut: relationship to the formation of enteric ganglia. J Comp Neurol 313:625-642.

Pomeranz HD, Rothman TP, Chalazonitis A, Tennyson VM, Gershon MD (1993) Neural crest-derived cells isolated from the gut by immunoselection develop neuronal and glial phenotypes when cultured on laminin. Dev Biol 156:341-361.

Prosser CL, Holzwarth MA, Barr L (1989) Immunocytochemistry of the interstitial cells of Cajal in the rat intestine. J Auton Nerv Syst $27: 17-25$

Rodriguez-Tébar A, Dechant G, Götz R, Barde Y-A (1992) Binding of neurotrophin-3 to its neuronal receptors and interactions with nerve growth factor and brain-derived neurotrophic factor. EMBO J 11: 917-922.

Rothman TP, Gershon MD (1982) Phenotypic expression in the developing murine enteric nervous system. J Neurosci 2:381-393. 
Rothman TP, Tennyson VM, Gershon MD (1986) Colonization of the bowel by the precursors of entcric glia: studies of normal and congenitally aganglionic mutant mice. J Comp Neurol 252:493-506.

Rothman TP, Le Douarin NM, Fontaine-Pérus JC, Gershon MD (1990) Developmental potential of neural crest-derived cells migrating from segments of developing quail bowel back-grafted into younger chick host embryos. Development 109:411-423.

Rothman TP, Le Douarin NM, Fontaine-Pérus JC, Gershon MD (1993) Colonization of the bowel by neural crest-derived cells re-migrating from foregut backtransplanted to vagal or sacral regions of host embryos. Dev Dyn 196:217-233.

Sagar SM, Edwards RH, Sharp FR (1991) Epidermal growth factor and transforming growth factor $\alpha$ induce $c$-fos gene expression in retinal Muller cells in vivo. J Neurosci Res 29:549-559.

Scarisbrick IA, Isaackson PJ, Jones EG (1993) Expression of NGF, BDNF, and NT-3 at sites of major tissuc interactions during development. Soc Neurosci Abstr 19:251.

Scheuermann DW, Stach W, Timmermans JP, Adriaensen D, De GroodtLasseel MHA (1989) Neuron-specific enolase and S-100 protein immunohistochemistry for defining the structure and topographical relationship of the different enteric nerve plexuses in the small intestine of the pig. Cell Tissue Res 256:65-75.

Serbedzija GN, Burgan S, Fraser SE, Bronner-Fraser M (1991) Vital dye labeling demonstrates a sacral neural crest contribution to the enteric nervous system of chick and mouse embryos. Development 111:857-866

Serio R, Barajas-Lopez C, Berezin I, Daniel EE, Huizinga JD (1991) Slow-wave activity in colon: role of network of submucosal interstitial cells of Cajal. Am J Physiol 260:G636-G645.

Sieber-Blum M (1991) Role of the neurotrophic factors BDNF and NGF in the commitment of pluripotent neural crest cells. Neuron 6:949-955.

Smalheiser N, Schwartz NB (1987) Cranin: a laminin-binding protein of cell membranes. Proc Natl Acad Sci USA 84:6457-6461.

Soppet D, Escandon E, Maragos J, Middlemas DS, Reid SW, Blair J, Burton LE, Stanton BR, Kaplan DR, Hunter T, Nikolics K, Parada LF (1991) The neurotrophic factors brain-derived neurotrophic factor and neurotrophin-3 are ligands for the trkB tyrosine kinase receptor. Cell 65:895-903.

Squinto SP, Stitt TN, Aldrich TH, Davis S, Bianco SM, Radziejewski C, Glass DJ, Masiakowski P, Furth ME, Valenzuela DM, DiStefano PS, Yancopoulos GD (1991) trkB encodes a functional receptor for brain-derived neurotrophic factor and neurotrophin-3 but not nerve growth factor. Cell 65:885-893.
Stemple DL, Mahanthappa NK, Anderson DJ (1988) Basic FGF induces neuronal differentiation, cell division, and NGF dependence in chromaffin cells: a sequence of events in sympathetic development. Neuron 1:517-525.

Teillet M-A (1978) Evolution of the lumbo-sacral neural crest in the avian embryo: origin and differentiation of the ganglionated nerve of Remak studied in interspecific quail-chick chimera. Wilhelm Rouxs Arch Dev Biol 184:251-268.

Tessarolo L, Tsoulfas P, Martin-Zanca D, Gilbert DJ, Jenkins NA Copeland NG, Parada LF (1993) $t r k C$, a receptor for neurotrophin3 , is widely expressed in the developing nervous and in non-neuronal tissues. Development 118:463-475.

Thuneberg L (1989) Interstitial cells of Cajal. In: The gastrointestinal system, Pt 1 (Wood JD, ed), pp 349-386. Bethesda, MD: American Physiological Society.

Tsoulfas P, Soppet D, Escandon E, Tessarollo L, Mandoza-Ramirez J-L, Rosenthal A, Nikolics K, Parada LF (1993) The rat $t r k C$ locus encodes multiple neurogenic receptors that exhibit differential response to neurotrophin-3 in PCl 2 cells. Neuron 10:975-990.

Tucker GC, Aoyama H, Lipinski M, Tursz T, Thiery J-P (1984) Identical reactivity of monoclonal antibodies HNK-1 and NC-1: conservation in vertebrates on cells derived from the neural primordium and on some leukocytes. Cell Differ 14:223-230.

Tucker GC, Delarue C, Zada M, Boucaut J-C, Thiery J-P (1988) Expression of the HNK-1/NC-1 epitope in early vertebrate neurogenesis. Cell Tissue Res 251:457-465.

Valenzuela DM, Maisonpierre PC, Glass DJ, Rojas E, Nuñez L, Kong Y, Gies DR, Stitt TN, Ip NY, Yancopoulos GD (1993) Alternative forms of rat TrkC with different functional capabilities. Neuron 10: 963-974.

Vincent M, Thiery J-P (1984) A cell surface marker for neural crest and placodal cells: further evolution in peripheral and central nervous system. Dev Biol 103:468-481.

Vincent M, Duband J-L, Thiery J-P (1983) A cell surface determinant expressed early on migrating avian neural crest cells. Dev Brain Res 9:235-238.

Zhou X-F, Rush RA (1993) Localization of neurotrophin-3-like immunoreactivity in peripheral tissues of the rat. Brain Res 621:189199.

Ziller C, Dupin E, Brazeau P, Paulin D, Le Douarin NM (1983) Early segregation of a neuronal precursor cell line in the neural crest as revealed by culture in a chemically defined medium. Cell $32: 627-$ 638 